\title{
WestVirginiaUniversity
}

THE RESEARCH REPOSITORY @ WVU

Graduate Theses, Dissertations, and Problem Reports

2000

\section{Exploring visitor meanings of place in the National Capital Parks - Central}

Wei-Li Jasmine Chen

West Virginia University

Follow this and additional works at: https://researchrepository.wvu.edu/etd

\section{Recommended Citation}

Chen, Wei-Li Jasmine, "Exploring visitor meanings of place in the National Capital Parks - Central" (2000). Graduate Theses, Dissertations, and Problem Reports. 1153.

https://researchrepository.wvu.edu/etd/1153

This Thesis is protected by copyright and/or related rights. It has been brought to you by the The Research Repository @ WVU with permission from the rights-holder(s). You are free to use this Thesis in any way that is permitted by the copyright and related rights legislation that applies to your use. For other uses you must obtain permission from the rights-holder(s) directly, unless additional rights are indicated by a Creative Commons license in the record and/ or on the work itself. This Thesis has been accepted for inclusion in WVU Graduate Theses, Dissertations, and Problem Reports collection by an authorized administrator of The Research Repository @ WVU. For more information, please contact researchrepository@mail.wvu.edu. 


\title{
EXPLORING VISITOR MEANINGS OF PLACE IN THE
}

NATIONAL CAPITAL PARKS-CENTRAL

\author{
Wei-Li Jasmine Chen
}

\begin{abstract}
Thesis submitted to the College of Agriculture, Forestry, and Consumer Sciences at West Virginia University in partial fulfillment of the requirements for the degree of
\end{abstract}

Master of Science in Recreation, Parks, and Tourism Resources

\author{
Steve Selin, Ph.D., Chair \\ Theresa L. Wang, Ph.D., Co-Chair \\ Steve Hollenhorst, Ph.D.
}

Department of Recreation, Parks, and Tourism Resources

\author{
Morgantown, West Virginia \\ 2000
}

Keywords: Interpretation, visitor meanings, place, connections, interpretive development program, National Park Service, Lincoln Memorial, Vietnam Veterans Memorial, Korean War Veterans Memorial, visitor study 


\begin{abstract}
Exploring Visitor Meanings Of Place In The National Capital Parks-Central
\end{abstract}

Wei-Li Jasmine Chen

This study uses a new approach to interpretative research based on (1) understanding the meanings visitors attach to park resources, and (2) examining the connections that visitors made after attending an on-site interpretive program. The study was conducted at the National Capital Parks in Washington, DC. This study revealed that many visitors to the Lincoln Memorial, the Vietnam Veterans Memorial, and the Korean War Veterans Memorial (i.e. the Triangle) seek something of value for themselves, including everything from connecting with the past and rededicating themselves to the ideals of the nation. The study incorporated mixed method design, including purposeful sampling for visitor interview participants, quasi-experimental pre-test/post-test design, focus group interview, and both quantitative and qualitative data analysis. During the summer of 1998, researchers conducted 89 focus group interviews and interviewed a total of 527 visitors. Study results suggest that visitors attach meanings and many of them desire quality interpretative experiences.

Keywords: interpretation, visitor meanings, place, connections, the Interpretive Development Program, National Park Service, Lincoln Memorial, Vietnam Veterans Memorial, Korean War Veterans Memorial, visitor study 


\section{ACKNOWLEDGEMENTS}

I would like to thank the following individuals for helping this thesis becoming a reality. First and foremost, I thank Dr. Theresa L. Wang for her excellent professional knowledge, unending patience during the editing process, and wisdom for understanding and letting me find a unique research phase and personal space. At the beginning, writing this thesis seemed an impossible task for me. Being a non-native English speaker, I had so many questions of the "ludicrous rules" of this very language. "Why can't I say this, but have to say that?" was a common question that I raised to her. She understands my frustration and always has an answer for me. I appreciate her advice, consultation, and encouragement throughout the project. Second, I thank Mr. David Larsen of Steven T. Mather Training Center, National Park Service, for his time, energy, knowledge, kindness, and vision that can not be missed throughout different phases of the processes. Meanwhile, I want to appreciate my committee members for their invaluable moral support and advice: Dr. Steve Selin and Dr. Steve Hollenhorst. I also want to acknowledge the following individuals for their contribution:

Dave Dahlen for his on-going support of the study and for his assistance at NAI research presentations in 1999.

Donna Donoldson for her logistical and political support which included determining the interview location, arranging the tent, chairs, tables, electricity, door prizes, and identifying $\mathrm{NCP}-$ Central staff to assist with this study.

Robert Fudge for his interpretation expertise, meaningful discussion, and sense of humor during the training sessions.

Sue Hansen for her encouragement, involvement, and timely support during the data collecting and training processes.

Loren Govering for his help with arranging interpreters' schedules and communicating with participating interpreters, and dealing with logistics of on-site research.

Wayne Braxton for using his special connections to obtain White House and Holocaust Museum tickets as door prizes which did lure a good number of participants.

Gerry Gaumer for his help with arranging interpreters' schedules and communicating with participating interpreters. 
Lee Wurstrest for his help with arranging interpreters' schedules, communicating with participating interpreters, and dealing with logistics of on-site research.

Bill Ellis for his assistance with transcribing two of the interviews and for his early affirmation regarding the value of this study.

Allyssa Baltrus for agreeing to participate in this study, demonstrating interpretive programs, and support.

Lowell Fry for agreeing to participate in this study, demonstrating interpretive programs, providing awesome assistance in recruiting participants, attending the training sessions, and sharing his insights and encouragement.

Rachel Gomez for agreeing to participate in this study, demonstrating interpretive programs, and support.

Jennifer Hildago for agreeing to participate in the study.

Gil Lyons for agreeing to participate in this study, demonstrating interpretive programs, providing awesome assistance on recruiting participants, attending the training sessions, and offering support and encouragement.

Christie Stanczak for agreeing to participate in this study, demonstrating interpretive programs, and attending the training sessions.

Roseanne Phfiffer for participating the training sessions and sharing her insights.

And the maintenance crew for their hardwork on setting up the interview tent, tables, and chairs, providing the electric hook-ups, and delivering the ice for comforting our participants.

In addition, I thank my family members for their distant, intangible, but invaluable support. We have the Pacific Ocean and more than half of the North America continent between us. Especially, it is not always easy for a father to let go of a daughter who has been a treasure and friend to him. Last but not least, I cherish and thank the many forms of love from Wen-Chang. Praise the Heavenly Father for the strength, support, and surroundings that he provides. I might be just beginning; I might be near the end. 
Abstract

ii

Acknowledgements

Table of Contents $\quad$ v

List of Table vii

$\begin{array}{ll}\text { List of Figures } & \text { viii }\end{array}$

List of Maps $\quad$ ix

$\begin{array}{ll}\text { Chapter One } & 1\end{array}$

Introduction

$\begin{array}{ll}\text { Chapter Two } & 3\end{array}$

Literature Review

Interpretation's Many Purposes and Functions $\quad 3$

The Interpretive Development Program 4

$\begin{array}{ll}\text { The Interpretive Equation and Interpretive Opportunity } & \mathbf{7}\end{array}$

Promoting Resource Stewardship and Effective Resource $\quad 9$

Management Requires Understanding Visitor Meanings of

Place

Place Research $\quad 11$

The Challenges of Interpretation at Memorial Sites $\quad \mathbf{1 5}$

$\begin{array}{lr}\text { Chapter Three } & 17\end{array}$

Methods

Objectives 17

Study Design $\quad 17$

Site Selection $\quad 18$

Focus Group Interviews $\quad \mathbf{2 1}$

Data analysis $\quad \mathbf{2 2}$

Research Limitations $\quad \mathbf{2 3}$

$\begin{array}{ll}\text { Chapter Four } & \mathbf{2 6}\end{array}$

Results

Participant Demographics $\quad 26$

Word Frequencies $\quad 30$

A Summary of Participant Responses to the Interview 34

Questions

Themes $\quad 38$

Theme 1: The Triangle Embodies the Ideals of A Nation 38 and Functions as A Sacred Place 
Theme 2: Lincoln is a Symbol of Unity, Strength, and

Freedom

Theme 3: Visitors Have a Strong Sense of What Constitutes

A Quality Interpretive Program and On-site Experience at the Triangle

1. Tangible Experiences

2. Universal Concepts and Symbols 47

3. Intellectual and Emotional Connections $\quad 48$

4. Cohesive Development of an Idea 50

Theme 4: The Triangle Inspires a Sense of Gratitude for the $\mathbf{5 3}$

Sacrifices of Others and Stimulates A Desire to Participate in Democratic Life

\section{Chapter Five}

Discussion

Visitors Actively Ascribe Meanings to Site Resources

Visitors Seek An On-site Experience that Enables Them to

Make A Connection between the Tangible Resource \& Its Intangible Meanings

Many Visitors Want Their Experience to be Facilitated

Visitor Meanings Could Improve Interpretive Work

Management and Training Implication

\section{Chapter Six}

Conclusion

\section{Summary}

References

Appendixes

Appendix A. War Quotes

Appendix B. Lincoln Quotes

Appendix C. Democracy Quotes $\quad 91$

Appendix D. Patriotism Quotes $\quad 94$

Appendix E. Freedom Quotes 96

Appendix F. Intergeneration relationships Quotes 101

Appendix G. Interpretation relationships Quotes 104 


\section{LIST OF TABLES}

Table 1. Research in Meanings of Place

Table 2. Research in Place Attachment

Table 3. Research in Place Value

Table 4. Research in Place Dependence

15

Table 5. Keyword Frequencies 


\section{LIST OF FIGURES}

Figure 1. Participants Geographic Region 27

Figure 2. Participants Age Range 27

Figure 3. Number of Visits to NCP--Central 28

Figure 4. Participants Ethnic Background 28

Figure 5. A Ranger Linking a Tangible Resource with its 35 Intangible Meanings at the Lincoln Memorial 


\section{LIST OF MAPS}

Map 1. NCP-Central $\quad 19$

Map 2. The Triangle: Lincoln Memorial, Korean War 20

Veterans Memorial, \& Vietnam Veterans Memorial 


\section{Chapter One}

\section{Introduction}

"To be human is to live in a world that is filled with significant places: to be human is to have and know your place" (Relph, 1976, p. 1). British philosopher Edward Relph equates being human with understanding and connecting with personal and public places. Every year, visitors from the U.S. and other countries flock to National Capital Parks (NCP) to understand the place and to be spiritually charged. Visitors attach significant personal meanings to $\mathrm{NCP}-$ Central sites such as the Lincoln Memorial, the Vietnam Veterans Memorial, and the Korean War Veterans Memorial. Interpreters need to not only understand the resource, including its natural and human history, but also understand the audience, including their meanings of place and visitor expectations, to successfully facilitate a quality interpretive program.

Washington, DC holds a special place in the minds of Americans. NCP-Central park resources represent the ideals of the U.S. founding fathers. They provide a meeting ground for civic movements. And they remind visitors of important people and events in U.S. history. When interpretive rangers are overwhelmed by heavy daily responsibilities and visitors' "ludicrous questions" (Tilden, 1977, p. 46), it is easy to overlook how strongly visitors connect to these sites. For example, two visitors articulated the meanings these sites hold for them as follows:

Something that strikes me is not just Abraham Lincoln. I have a second cousin whose name we go to see on the Vietnam Wall. Our country stands for not just the heroes like Lincoln, but all people. That is what I think of all those monuments. It is really wonderful to live in a country that lifts up Lincoln and my cousin (Woman, Post 1, p. 4).

This setting is being used for this one concept-freedom. Which isMartin Luther King said in his great speech—-Let freedom ring." And there's a lot of people in the country who say are we free or aren't we free? But freedom comes at a great cost with the lives that were lost in the wars (Man, Pre 1, p. 1). 
This study addresses the four reasons why interpreters need to understand visitor meanings of place. Understanding visitors' meanings can help to:

- Increase interpreters' knowledge of their audience.

- Regenerate the interpreters' passion toward both the resources and the visitors.

- Facilitate the incorporation of multiple points of view into onsite interpretation.

- Facilitate visitor connections and desired interpretive outcomes.

This study explored the meanings visitors attach to the Lincoln Memorial, the Vietnam Veterans Memorial, and the Korean War Veterans Memorial, which are located in National Capital Parks-Central in Washington, DC. The study also examined the connections visitors made between the meanings of the resources and their own personal interests through attendance at ranger-led interpretive programs. Chapter two reviews the scholarly literature related to the principles of effective interpretation, meanings of place, place attachment, and desired interpretive outcomes. Chapter three outlines the research methods used in this project, providing readers with a comprehensive view of the research process. Chapter four presents the research results. Chapter five discusses the study findings and provides interpretative training, program development, and planning recommendations.

The results of this study suggest that the reasons why people visit the National Mall encompass more than simply "wanting to see the site" and "learning about U.S. history" (Littlejohn \& Hoffman, 1999, p. 17). Physically being in a place, experiencing the overall landscape, and thinking through the historic events that have taken place at that site, or that are commemorated at the site, is an extremely rich sensory activity. At $\mathrm{NCP}$-Central, place experience occurs through a combination of both affective and cognitive processes. Visitors seek something of value for themselves; this may include connecting with the past at one end of the spectrum to rededicating oneself to the ideals of the nation at the other. At the National Capital Parks-Central, understanding visitor meanings should enable interpreters to do a better job of providing interpretive opportunities, stimulating an ethic of resource stewardship, and fostering a commitment to participatory lifestyle. 


\section{Chapter Two}

\section{Literature Review}

Interpretation benefits visitors by helping them understand the intrinsic and material values of the inherent natural and heritage resource, by promoting civic awareness of environmental and social issues, and by encouraging them to participate in responsible citizenship (Wager, 1978). From the park management perspective, interpretation not only reduces vandalism and maintenance costs, but also provides a mechanism for communicating the organizational mission to the visitors (Lustig, 1982; Griest \& Mullins, 1984). Wang (1998) defines interpretation and addresses the functions of interpretation as follows:

Interpretation relates the purpose and significance of a natural area or heritage site, introduces outstanding natural or cultural features, explains how natural or social systems function(ed) in the past and present, and translates scientific concepts or diverse cultural perspectives into ideas easily understood by the public. Interpretation facilitates a visitor's sense of connection to the resource. Interpretation is also a mechanism for the public land managing agencies to communicate their mission to the public and build support for that mission (Wang, 1998, p. 1).

\section{$\underline{\text { Interpretation's Many Purposes and Functions }}$}

Researchers have identified a range of interpretation's functions. Visitors attending interpretive programs gain an in-depth understanding of U.S. heritage, and the people and events of cultural significance (Trotter, 1992). Besides the basic service of park orientation, interpretation enriches park visitors' experiences by providing programs that increase their understanding of natural processes such as glaciation and forest succession, or aspects of human history such as war and peace (Roggenbuck, Williams, \& Bobinski, 1992; Masberg, 1996). Interpretation communicates the intrinsic and material values of the resources (Wagar, 1978; Cherem, 1977; Trotter, 1992). Interpretation also functions as a way to instill (or question) the beliefs that undergird the 
government structure, a sense of cultural identity, or an ethical relationship to the natural world (Kubel \& Leone, 1997). For public land management agencies, such as the National Park Service (NPS), the Fish and Wildlife Service, and the USDA Forest Service, interpretation functions as a powerful management tool for provoking resource stewardship and civic engagement (Wagar, 1978; Forest Service, 1990; Roggenbuck et al., 1992; Zinsser, 1992; Hilten \& Hilten, 1997).

\section{The Interpretive Development Program}

By creating the Interpretive Development Program (IDP), the National Park Service has recently taken the lead in advancing interpretive principles and theory and establishing a mechanism for improving interpretive practice (NPS, 1997). Previous interpretive training efforts in the NPS focused on getting interpreters "trained." The IDP, however, outlines an improved conceptual foundation for effective interpretation and provides a mechanism for interpreters to demonstrate success in ten clearly-defined interpretive competencies (Larsen, 1998; Wang, 1998). In short, the Interpretive Development Program successfully integrates interpretive theory and practice, ensuring interpreter competence through a rigorous certification process. The IDP is based upon three tenets, including:

Tenet 1: Resources possess meanings and have relevance.

Tenet 2: Visitors seek something of value for themselves.

Tenet 3: Interpretation facilitates a connection between the meanings of the resource and the interests of the visitor (Larsen, n.d.).

The Park Service maintains that all effective interpretation links tangible resources to intangible resources to reveal meanings. Tenet one emphasizes that resources are imbued with meanings, inherent and ascribed, and that these meanings

make the resources relevant to people's lives today. Tenet two stresses that visitors approach a resource seeking something of value, something that will enrich their lives. Tenet three suggests the importance of interpreting multiple perspectives of park resources and respecting visitors' sovereignty. Presenting multiple points of view makes 
parks more meaningful to a wider range of individuals and provides multiple points of access to the interpretive message.

Landscape architects, environmental psychologists, and cultural geographers have a long history of examining the how people attach meanings to a given geographic locale or the environment. An in-depth discussion of this subject occurs in a later section (see pp. 11-15).

Respecting visitor sovereignty and understanding their interests can lead to desired interpretive outcomes. An interpretive specialist with the National Park Service, David Larsen emphasizes visitors' sovereignty in the interpretive process by saying:

All visitors have a right to their own values and perspectives. Ultimately each visitor determines the effectiveness of any rule or preservation message. The visitor judges the significance of their own experience and ascribes worth to the resource..... (Larsen, n.d., p. 4).

For Larsen, stewardship occurs only when the visitors begin to care about the past, present, and future meanings and values of the resource, so that, they begin to actively, care for the resource (Larsen, n.d.). Interpretation plays an important role in expanding and deepening visitors' thoughts and beliefs. Successful interpretation meets visitors where they are and moves them along a stewardship continuum, which actually reflects the extent to which visitors are actively engaged in caring for park resources. Larsen also believes that unless park visitors come to care about park resources via interpretation or other significant personal experiences, they will not begin to care for the resource; and ultimately, the preservation of that resource will be jeopardized.

Before the development of the IDP, Ham (1992) emphasized the importance of inspiring a sense of care among the audience through interpretive programs: "Interpreters must not only find a way to link the information being presented to something their audiences know about, but something they care about. With noncaptive audiences, this is especially important because they'll almost always ignore information that seems unimportant, even if they understand it perfectly" (p. 13).

The IDP also emphasizes the importance of incorporating universal concepts into interpretation. Universal concepts are the ideas that are relevant to almost everyone such 
as beauty, family, change, survival, power, and freedom. Ham (1992) identifies these concepts as "highly personal things" including, "ourselves, our families, our health, our well-being, our quality of life, our deepest values, principles, beliefs and convictions" (p. 13). Ham urges interpreters to incorporate these concepts and connect them to the inner circle of their lives. Larsen (1997) declares that "successful interpretation need not move us to tears-it has to provoke us to care" (p. 19). Wager (1975) suggested that universal concepts can be used to tap into the memories, values and experiences that many visitors share. Provocation occurs through the use of universal concepts to make personalized meanings more salient. Beyond simple provocation, however, interpreters must facilitate a connection between the interests of the visitor and the meanings of the resource. Loomis (1996) suggests the importance of facilitating this visitor interest/resource meanings connection: "Interpretation should not only raise curiosity (attract central attention) but also provide opportunities for involvement by relating content to personal meanings" (p. 41).

Connections are defined in the IDP Module 101 as (1) "linkages" and "relationships" that are " broad based and accessible both intellectually and emotionally" (Larsen, 1997; NPS, 2000; NPS, 1997) and, (2) as the linkages that visitors forge with the resources when they "develop an active stewardship ethic" (NPS, 2000). Ham (1992) addresses the issue of connection by referring to two terms in psychological research: shadowing and selective attention. Shadowing is the phenomenon by which humans almost always react to or recall the more familiar of two messages. Familiarity allows the human brain to expend less effort to concentrate on personal and meaningful content (Moray, 1959; Cherry, 1966). Selective attention is referred to as people switching their attention to things they care about even when they are not consciously trying to (Solso, 1979). Ham (1992) concludes that "The best communicators always try to connect their ideas to the lives of their audiences." He said,

When information is meaningful it's because we're able to connect it to something already inside our brains. Meaningful information is said to have "context" since we understand it only in the context to something else we already know... [We] attach a meaning to it that is based on the 
words it awakened in our minds. When something we hear or see doesn't connect with anything we already know, it's meaningless to us (p. 12).

Martinez (1988) urges interpreters to "make an honest effort to show to the visitor the many sides of the story... acting as a mediator of history, provoking the audience, and letting them ponder and decide" (p. 146, 152). To successfully facilitate connections, an interpreter must understand their audience. Trotter (1992) stresses the importance of having an in-depth understanding of the meanings and belief systems that visitors bring with them when designing an interpretive program. He argues that, "Humans carry their cultural values everywhere they go, and act out of those values, whatever they do" (p. 130). Finally, an in-depth understanding of their audience should influence how interpreters choose to communicate resource meanings. Wagar (1975) highlighted the communication challenges interpreters face when he said:

Interpreters must often communicate with people whose memories, thought processes, and word associations are quite different from each other. The most effective interpreters are those with a knack for translating meanings from one system of symbols (often the scientist's) into another (the visitor's) (p. 7).

As a result, the job of the interpreter is to facilitate (not dictate) the individual's personal connections to the resource and the formation of their own unique meanings.

\section{The Interpretive Equation and Interpretive Opportunity}

An important component of the NPS's Interpretive Development Program is the interpretive equation (NPS, 2000; NPS, 1999; Larsen, n.d.; Larsen, 1998). The interpretive equation is written as follows:

$$
\left(K_{R}+K_{A}\right) A T=I O
$$

The interpretive equation highlights the key factors that contribute to effective interpretation. In the equation, $\mathbf{K}_{\mathbf{R}}$ represents the interpreter's "knowledge of the resource," $\mathbf{K}_{\mathbf{A}}$ represents the interpreter's "knowledge of the audience," AT represents 
the interpreter's use of an "appropriate technique," and IO represents the production of an "interpretive opportunity" for visitors. An interpretive opportunity may lead to the desired outcome of interpretation-that is, the visitor may form "intellectual and emotional connections" with the meanings of the resource and ultimately, come to care for the resource. Again, however, "the visitor is sovereign and will ultimately decide on the meanings, value, and preservation of the resource" (Larsen, n.d., p. 8).

In general, research studies are not well-distributed among the four areas represented by the interpretive equation: knowledge of the resource, knowledge of the audience, appropriate technique and interpretive opportunity. Specifically, appropriate techniques and interpretive outcomes (not equal to the $\mathbf{I O}$ in the equation) have been the focus of most interpretive research, while knowledge of the resource and knowledge of the audience have not been well explored in research studies. Research on appropriate techniques explores the advantages and disadvantages of various interpretive media and methods (Mahaffey, 1970; Reyburn \& Knudson 1980; Hammit, 1982). Another common research topic is to examine the extent to which interpretive programs yield desired interpretive outcomes. Research in this area has focused on interpretive effectiveness, attitude and behavior change, the decrease of vandalism, and the quality of visitor experiences (Hayward \& Larkin, 1983; Griest \& Mullins, 1984; Cable, Knudson, Udd, \& Stewart, 1987; Trotter, 1989; Bitgood, 1994; Milton, Cleveland, \& Bennett-Gates, 1995).

Even though less studied, several scholars have indicated that interpreter's knowledge of the audience is a needed area of research (Masberg \& Silverman, 1996; Trotter, 1992; Wagar, 1975; Wagar, 1978). Others emphasize the significance of understanding the various domains of the audience in their writings. Tilden (1977), the pioneer of interpretive philosophy, indicates the importance of understanding audience interests. In his first interpretive principle, he urges interpreters to attempt to identify visitors' chief interests. Tilden emphasizes that "the visitor's chief interest is in whatever touches his personality, his experience and his ideals" (p. 11). He also suggests that interpreters build upon pre-existing visitor knowledge by "[letting] the talk turn to something the visitor already knows" (p. 46). Interpreters need to focus not only on an in-depth, scientific knowledge of the resources, but also on an understanding of which attributes are important to the whole person-for example, religious or spiritual 
connections with nature, the emotions, the yearning for continuity, and the love of a story. Martinez (1988) states that by understanding visitors' "preconceived ideas" and "sincere interests," interpreters may increase the likelihood of "building the bridge" between visitors and the resource. Ham (1992) highlights "interpreters who understand why and how audience such as these differ, and even more important, how to tailor communication methods to suit them, have a distinct advantages over interpreters who don't" (p. 6).

There is a large body of research on several related topics, however, including: audience demographics (Rakow \& Lehtonen, 1988; Wallace \& Witter, 1991), visitor motivation and benefits (More, 1983; Rakow \& Lehtonen, 1988; Hungerford \& Volk, 1990; Wallace \& Witter, 1991), and the learning process (Hammit, 1982; Meredith \& Mullins, 1995; Ham \& Krumpe, 1996). Several articles have explored the characteristics of a quality interpreter (Cherem, 1977; Brockman, 1978; Lustig, 1982; Mullins, 1984).

\section{Promoting Resource Stewardship and Effective Resource Management Requires}

\section{Understanding Visitor Meanings of Place}

In search of a more holistic and integrated approach to understanding human motivations, physical and psychological engagement, activities, and benefits of a given "place," researchers and natural resource managers have emphasized the importance of understanding peoples' meanings of place and suggested applying the sense of place concept in resource management (Roggenbuck et al. 1992; Masberg 1996; William \& Stewart 1998; Galliano \& Loeffler 1999). Recent studies have employed various methods in exploring and documenting the relationships among recreation resources, resident and visitor meanings and perspectives of place, and the likelihood of participating in resource stewardship (Selin \& Howard, 1988; Williams, Patterson, Roggenbuck, \& Watson, 1992; Brandenburg \& Carroll 1995; Milton, Cleveland, \& Bennett-Gates, 1995; Galliano \& Loeffler 1999). McCool, Stankey, \& Clark (1985) highlight that it is the context within which recreation takes place that can facilitate or hinder not only the activities that occur but also the quality of the recreation experience.

Largely agreed among the researchers about the importance of understanding people's meanings of place, however, Williams \& Steward (1998) declare that the 
concept itself is "elusive, ill defined, and controversial" (p. 18). Nonetheless, Williams \& Stewart (1998) define a sense of place as "the collection of meanings, beliefs, symbols, values, and feelings that individuals or groups associate with a particular locality" (p. 19). Simonson (1989) believes that a sense of place "restores one's relationship to the land and the community, and therefore to oneself." Buttimer (1980) purposes that people ascribe symbolic, emotional, cultural, political, and biological meanings to place.

Landscape architects and city planners have expressed an interest of understanding how people visually prefer one landscape from another (Lynch, 1960; Appleyard, 1979; Hester, 1985). Thriving from those observations, geographers and environmental psychologists are among the earliest professionals to explore and identify the phenomenon of how places reveal meanings and how humans attach meanings to places (Moore \& Graefe, 1994). A cultural geographer, Tuan $(1974,1977)$ describes place as a center of meanings that are formed through experience. He stresses that a physical space becomes place when we attach personal or group meanings to a particular geographic locale. For example, one may attach a range of personal meanings to one's home and homeland-be it a chair in the living room, one's neighborhood, city, region, or nation. A group of people may also relate to a specific place as an object that symbolizes their beliefs and values (Tuan, 1976). Ryden (1993) identifies four elements of place: personal memory, community history, physical landscape appearance, and emotional attachment. Geographers then suggest that through attaching personal or group meanings to place, people acquire a sense of belonging and purpose that can give meaning to their lives (Relph, 1976; Buttimer, 1980; Tuan, 1980). Frequently referred to by recreation researchers, the concept of sense of place and place attachment have been incorporated, examined, and further explained from an approach of place-dependence (Jacob \& Schreyer, 1980; Schreyer \& Roggenbuck, 1981; Williams et al., 1992). Stokols and Shumaker (1981) defined the notion of place-dependence as a form of attachment associated with the potential of a particular place to satisfy the needs and goals of an individual. Place dependence can be lessened if there are other currently available settings that may satisfy the same set of needs.

The second approach to sense of place has been explained by environmental psychologists as place-identity (Proshansky, 1978; Proshansky, Fabian, \& Kaminof, 
1983). Proshansky and associates describe the concept of "place-identity" as "those dimensions of the self that define the individual's personal identity in relation of the physical environment" (Proshansky, 1978, p. 155).

\section{$\underline{\text { Place Research }}$}

Given the many dimensions of the concept, it has been a challenge to quantify or measure place meanings, place attachment, place dependence, and place identity (Williams \& Stewart, 1998). A growing number of studies have been conducted to help quantify, measure, and elucidate the meanings of place. Most of these studies have chosen to adopt one of the following indicators: meanings of place, place attachment, place values, place dependence, or a combination these elements.

1. Meanings of place. A large body of the existing studies employed this approach to examine the collection of meanings, beliefs, symbols, values, and feelings that individuals or groups associate with a particular locality.

A summary of these studies is presented in Table 1.

\section{Table 1. Research in Meanings of Place}

\begin{tabular}{|c|c|c|c|}
\hline Study & Areas of Focus & Settings & Methods \\
\hline $\begin{array}{l}\text { Fishwick \& } \\
\text { Vining, } 1992\end{array}$ & $\begin{array}{l}\text { - The meanings and values associated with } \\
\text { preferred outdoor recreation sites } \\
\text { - The quality of landscape that infuse an outdoor } \\
\text { recreation setting with a sense of place for } \\
\text { individuals } \\
\text { - The importance of these landscape in the } \\
\text { contexts of people's lives }\end{array}$ & $\begin{array}{l}\text { Illinois State } \\
\text { Parks }\end{array}$ & $\begin{array}{l}\text { Problem- } \\
\text { solving activity; } \\
\text { Rating } \\
\text { Interviews }\end{array}$ \\
\hline $\begin{array}{l}\text { Beeson et al., } \\
1996\end{array}$ & $\begin{array}{l}\text { - People's interaction with the site } \\
\text { - } \quad \text { The development of a place-identity. }\end{array}$ & $\begin{array}{l}\text { Gunnison } \\
\text { National } \\
\text { Forest, } \\
\text { Colorado }\end{array}$ & Interview \\
\hline Jones, 1996 & $\begin{array}{l}\text { - The measurement of a sense of belonging } \\
\text { - The relationship of a sense of belonging and } \\
\text { visitor characteristics }\end{array}$ & $\begin{array}{l}\text { Cumberland } \\
\text { Gap National } \\
\text { historic Park }\end{array}$ & $\begin{array}{l}\text { A nomological } \\
\text { network of } \\
\text { observable } \\
\text { properties }\end{array}$ \\
\hline Stedman, 1996 & - People's place identity through hunting & N/A & $\begin{array}{l}\text { Cognitive } \\
\text { mapping }\end{array}$ \\
\hline
\end{tabular}




\begin{tabular}{|c|c|c|c|}
\hline $\begin{array}{l}\text { Bricker \& } \\
\text { Kerstetter, } \\
1997\end{array}$ & $\begin{array}{l}\text { - The sense of place for whitewater recreationists } \\
\text { (rafters \& kayakers) }\end{array}$ & $\begin{array}{l}\text { American } \\
\text { River, } \\
\text { California }\end{array}$ & $\begin{array}{l}\text { Survey; } \\
\text { Open-ended } \\
\text { questionnaires } \\
\text { Content analysis }\end{array}$ \\
\hline $\begin{array}{l}\text { Wasserman, } \\
1998\end{array}$ & $\begin{array}{l}\text { - Identification of the types and ranges of } \\
\text { intellectual, emotional, spiritual, \& communal } \\
\text { functions of memorial landscape: a sense for } \\
\text { memory, a sense for mourning, a sense for } \\
\text { reflection \& healing, a sense for ceremony, a } \\
\text { sense for collective action }\end{array}$ & $\begin{array}{l}\text { Memorial } \\
\text { landscape }\end{array}$ & $\begin{array}{l}\text { Review of } \\
\text { landscape } \\
\text { architecture } \\
\text { literature: } \\
\text { environmental } \\
\text { design \& urban } \\
\text { planning }\end{array}$ \\
\hline Galliano \& & - Identification of the "special places" & Interior & Interview \\
\hline Loeffler, 1999 & $\begin{array}{l}\text { Identification of the existence of personal and } \\
\text { group place meanings } \\
\text { Examination of how people describe these } \\
\text { places } \\
\text { - Exploration of whether a sense of place affects } \\
\text { future resource stewardship }\end{array}$ & $\begin{array}{l}\text { Columbia } \\
\text { Basin, } \\
\text { Washington }\end{array}$ & $\begin{array}{l}\text { Open-ended } \\
\text { questionnaire }\end{array}$ \\
\hline $\begin{array}{l}\text { Henderson \& } \\
\text { King, } 1999\end{array}$ & $\begin{array}{l}\text { - The personal and group motivations of using the } \\
\text { place among youth groups } \\
\text { The meanings and the intensity of depending on } \\
\text { the place } \\
\text { - The willingness of participating future activities } \\
\text { on site } \\
\text { - The alternative activities other than the on-site } \\
\text { activities }\end{array}$ & $\begin{array}{l}\text { Teen centers } \\
\text { in } \\
\text { southeastern } \\
\text { U.S. cities }\end{array}$ & $\begin{array}{l}\text { Case study } \\
\text { Multi-purpose } \\
\text { approach }\end{array}$ \\
\hline
\end{tabular}

2. Place attachment. Literatures on place attachment discuss the range and intensity of people's emotional bonds and/or relationship with a given place. A Likertscaled survey was frequently chosen for participants to indicate their levels of attachment. A summary of these studies is presented in Table 2. 


\section{Table 2. Research in Place Attachment}

\begin{tabular}{|c|c|c|c|}
\hline Study & Areas of Focus & Settings & Methods \\
\hline $\begin{array}{l}\text { Williams \& } \\
\text { Roggenbuck, } \\
1989\end{array}$ & $\begin{array}{l}\text { - Attachment on resource dependence } \\
\text { - } \quad \text { Attachment on resource identity }\end{array}$ & $\begin{array}{l}\text { Hypothesized } \\
\text { recreation } \\
\text { places }\end{array}$ & $\begin{array}{l}\text { A Likert-scaled } \\
\text { attachment } \\
\text { statements }\end{array}$ \\
\hline $\begin{array}{l}\text { Williams et al., } \\
1992\end{array}$ & $\begin{array}{l}\text { - } \begin{array}{l}\text { Previous use of wilderness, study site, and } \\
\text { - }\end{array} \text { Sobstitutability } \\
\text { - } \quad \text { Mode of experiences and trip characteristics } \\
\text { - } \quad \text { Sensitivity to various recreational impacts and } \\
\text { wilderness conditions }\end{array}$ & $\begin{array}{l}\text { Wilderness } \\
\text { areas ( } 3 \text { in } \\
\text { Montana, } 1 \text { in } \\
\text { Georgia) }\end{array}$ & $\begin{array}{l}\text { Survey; } \\
\text { Likert-scaled } \\
\text { statement on } \\
\text { place \& } \\
\text { wilderness } \\
\text { meanings \& } \\
\text { attachment }\end{array}$ \\
\hline $\begin{array}{l}\text { Mitchell et al., } \\
1993\end{array}$ & $\begin{array}{l}\text { - Emotional attachments to the national forest } \\
\text { - The differences among various user categories }\end{array}$ & $\begin{array}{l}\text { Chiwawa } \\
\text { River } \\
\text { drainage, } \\
\text { Washington }\end{array}$ & $\begin{array}{l}\text { Personal } \\
\text { interviews; } \\
\text { Grounded } \\
\text { theory }\end{array}$ \\
\hline $\begin{array}{l}\text { McCool \& } \\
\text { Martin, } 1994\end{array}$ & $\begin{array}{l}\text { - The relationship between tourism attitudes, } \\
\text { length of residency, level of tourism } \\
\text { development, \& feelings of community } \\
\text { attachment }\end{array}$ & Montana & $\begin{array}{l}\text { Survey; } \\
\text { Phone } \\
\text { interviews }\end{array}$ \\
\hline $\begin{array}{l}\text { Moore \& } \\
\text { Graefe, } 1994\end{array}$ & $\begin{array}{l}\text { - } \quad \text { Frequency/intensity of use } \\
\text { - } \quad \text { Level of place attachment } \\
\text { - } \quad \text { Level of place dependence } \\
\text { - } \quad \text { Degree of place identity }\end{array}$ & $\begin{array}{l}\text { Rail-trail } \\
\text { (Iowa, } \\
\text { Florida, \& } \\
\text { California) }\end{array}$ & $\begin{array}{l}\text { Interviews; } \\
\text { Likert-scaled } \\
\text { statement on } \\
\text { meanings and } \\
\text { statement }\end{array}$ \\
\hline $\begin{array}{l}\text { Fly \& Tarrant, } \\
1996\end{array}$ & $\begin{array}{l}\text { - The types of community attachment may be } \\
\text { influenced by land ownership patterns }\end{array}$ & $\begin{array}{l}\text { Southern } \\
\text { Appalachia }\end{array}$ & $\begin{array}{l}\text { Place } \\
\text { attachment scale }\end{array}$ \\
\hline $\begin{array}{l}\text { Mowen \& } \\
\text { Williams, } \\
1996\end{array}$ & $\begin{array}{l}\text { - The relationships of place attachment and } \\
\text { activities } \\
\text { - Trip expenditures } \\
\text { - Trip benefits/meanings }\end{array}$ & $\begin{array}{l}\text { Mount Rogers } \\
\text { National } \\
\text { Recreation } \\
\text { Area }\end{array}$ & Survey \\
\hline $\begin{array}{l}\text { Freye \& } \\
\text { Virden, } 1998\end{array}$ & $\begin{array}{l}\text { - The general importance of the natural settings } \\
\text { - The examination of how personal and cultural } \\
\text { experiences can lead to attachments to natural } \\
\text { environment }\end{array}$ & $\begin{array}{l}\text { Navajo } \\
\text { Reservation, } \\
\text { New Mexico }\end{array}$ & Interview \\
\hline
\end{tabular}


3. Place values. Several studies measured the values associated with or assigned to a given place or an ecosystem. Place values are often linked to management. For example, Grumbine (1994) argues that "Ecosystem management is an early stage in a fundamental reframing of how humans value nature" (p. 34). Results of these studies usually suggest one or more value shifts among resource managers, academic professionals, and users (both residents and visitors). A summary of these studies is presented in Table 3.

\section{Table 3. Research in Place Values}

\begin{tabular}{|c|c|c|c|}
\hline Study & Areas of Inquiry & Settings & Methods \\
\hline $\begin{array}{l}\text { Schroeder, } \\
1991\end{array}$ & Preferences \& meanings of a arboretum & $\begin{array}{l}\text { Arboretum } \\
\text { landscape }\end{array}$ & N/A \\
\hline $\begin{array}{l}\text { Brandenburg } \\
\text { \& Carroll, } \\
1995\end{array}$ & $\begin{array}{l}\text { The geographic relationship to an area } \\
\text { - The personal interaction with a landscape } \\
\text { - The exclusiveness of economic dependence on } \\
\text { the resource } \\
\text { - People's preferences, values, and beliefs related } \\
\text { to national forest land use }\end{array}$ & $\begin{array}{l}\text { A river } \\
\text { drainage area } \\
\text { in a national } \\
\text { forest, } \\
\text { Washington }\end{array}$ & $\begin{array}{l}\text { In-depth } \\
\text { interviews; } \\
\text { Qualitative } \\
\text { analysis }\end{array}$ \\
\hline $\begin{array}{l}\text { Schroeder, } \\
1996\end{array}$ & - Values associated with the "special places" & $\begin{array}{l}\text { Black River, } \\
\text { Michigan }\end{array}$ & N/A \\
\hline $\begin{array}{l}\text { Ballinger \& } \\
\text { Manning, } \\
1997\end{array}$ & $\begin{array}{l}\text { The values assigned by local residents } \\
\text { - The types of places in the park that are } \\
\text { important to the local character and the values } \\
\text { assigned to such places by local residents }\end{array}$ & $\begin{array}{l}\text { Acadia } \\
\text { National Park, } \\
\text { Maine }\end{array}$ & $\begin{array}{l}\text { Interviews on } \\
\text { open-ended } \\
\text { questions; } \\
\text { Preference } \\
\text { rating }\end{array}$ \\
\hline $\begin{array}{l}\text { Bengston \& } \\
\mathrm{Xu}, 1995\end{array}$ & $\begin{array}{l}\text { Four values associated with national forest: } \\
\text { - Economic/utilitarian } \\
\text { : } \text { Life support } \\
\text { - } \text { Mosthetic } \\
\end{array}$ & $\begin{array}{l}\text { National } \\
\text { forests }\end{array}$ & Content analysis \\
\hline $\begin{array}{l}\text { Crawford, } \\
1998\end{array}$ & $\begin{array}{l}\text { The relationships between environmental values and } \\
\text { individual votes } \\
\text { - Anthropocentric reformism } \\
\text { - Environmental ethics } \\
\text { - Radical ecophilosophy }\end{array}$ & Missouri & N/A \\
\hline
\end{tabular}


4. Place dependence: The willingness or ability to substitute a given place with another has been used in describing the intensity of place attachment. Some researchers were interested in how much people are willing to recreate in the willingness of people to switch to another setting if the ideal setting was closed or access were denied (Cooksey et al., 1982; Henderson \& King, 1999). Summary of these studies are compiled in Table 4.

Table 4. Research in Place Dependence

\begin{tabular}{|c|c|c|c|}
\hline Study & Areas of Focus & Settings & Methods \\
\hline $\begin{array}{l}\text { Cooksey et al., } \\
1982\end{array}$ & - Psychological attributes over ten environments & N/A & Survey \\
\hline $\begin{array}{l}\text { Williams et } \\
\text { al., } 1992\end{array}$ & $\begin{array}{l}\text { - Previous use of wilderness, study site, and } \\
\text { substitutability } \\
\text { - Willingness to substitute the visit }\end{array}$ & $\begin{array}{l}\text { Wilderness } \\
\text { areas ( } 3 \text { in } \\
\text { Montana, } 1 \text { in } \\
\text { Georgia) }\end{array}$ & $\begin{array}{l}\text { Likert-scaled } \\
\text { statement on } \\
\text { wilderness } \\
\text { meanings \& } \\
\text { attachment }\end{array}$ \\
\hline $\begin{array}{l}\text { Moore \& } \\
\text { Graefe, } 1994\end{array}$ & $\begin{array}{l}\text { - } \quad \text { Frequency/intensity of use } \\
\text { - Level of place attachment } \\
\text { - } \\
\text { Degree of place dependence }\end{array}$ & $\begin{array}{l}\text { Rail-trail } \\
\text { (Iowa, } \\
\text { Florida, \& } \\
\text { California) }\end{array}$ & $\begin{array}{l}\text { Interviews; } \\
\text { Survey; }\end{array}$ \\
\hline $\begin{array}{l}\text { Henderson \& } \\
\text { King, } 1999\end{array}$ & $\begin{array}{l}\text { The substitute place for the youth center } \\
\text { The substitute activity for going to the youth } \\
\text { center }\end{array}$ & $\begin{array}{l}\text { Teen centers } \\
\text { in } \\
\text { southeastern } \\
\text { U.S. cities }\end{array}$ & $\begin{array}{l}\text { Case study } \\
\text { Multi-purpose } \\
\text { approach }\end{array}$ \\
\hline
\end{tabular}

The Challenges of Interpretation at Memorial Sites

Interpretation research has highlighted the unique challenges and opportunities associated with interpreting natural and cultural resources, like those at the $\mathrm{NCP}-$ Central, that reflect diverse meanings such as war and peace, freedom and slavery, and commemorate national leaders and common heroes (Martinez, 1988; Machlis, 1992; Bennett, 1998). The war/peace memorials have a greater responsibility than other types of sites to interpret multiple perspectives of park resources. Martinez addresses the mostly negative emotions that visitors experience when visiting sites such as the USS Arizona Memorial and the Little Big Horn Battlefield National Monument (formerly the Custer Battlefield National Monument) where "history lives and the unmistakable specter 
of controversy thrives" (Martinez, 1988, p. 144). At the USS Arizona Memorial, both WWII veterans and Japanese visitors (and/or visitors of Japanese descent) have found the interpretative signs offensive. The Little Big Horn indeed reflects the dark side of the American government's political agenda and motives and the painful wounds inflicted upon the society and psyche of Native Americans. Bennett (1998) identifies the challenge posed by the war/peace memorials, which is to "represent the human pain and sorrow of war instead of the valor and glory of warriors and nations" (p. 8). Machlis (1992) reminds us that war has impacts beyond the immediate deaths of soldiers and civilians. Interpretive programs ought to seize the chance to discuss broader social and environmental impacts such as increased disease, general malnutrition, destruction of habitat, increased pollution, higher prices, and demographic change. By discussing the event comprehensively, interpreters can reach an audience who themselves have diverse beliefs about the cultural politics of war and peace.

The IDP links interpretive theory and practice. Quality interpretation requires an effort to integrate knowledge of the resource, knowledge of the audience, and appropriate techniques to yield desired interpretive outcomes. Understanding visitors' meanings of place can increase interpreters' knowledge of their audience and regenerate interpreters' passion toward both the resource and the visitors. Interpretive mangers and front-line interpreters need a more comprehensive understanding of the meanings that visitors bring to sites as well as the ability to apply that understanding to the development of interpretive programs. Interpretation at $\mathrm{NCP}$-Central challenges both front-line interpreters and interpretive supervisors to consider how to communicate diverse meanings of war and peace, freedom and slavery, and related issues to visitors. It also challenges interpreters to facilitate a connection between the meanings of the resource and the interests of the visitors. To help interpreters achieve desired interpretive outcomes, this study explores the meanings that visitors attach to the resources at the triangle region of $\mathrm{NCP}-$ Central. 


\section{Chapter Three}

\section{Methods}

\section{$\underline{\text { Objectives }}$}

The study employed an exploratory approach that seeks to identify and examine the meanings that visitors attach to three sites at the National Capital Parks-Central. They study also examine the increase and expand of connections that visitors made after attending an on-site ranger-led interpretive program. Study objectives include:

1. To identify the meanings visitors attach to three NCP-Central sites: the Lincoln Memorial, the Korean War Veterans Memorial, and the Vietnam Veterans Memorial. (These sites constitute an area known as "the Triangle.")

2. To identify visitor interests regarding interpretive programs and quality on-site experiences.

3. To identify the type of connections between the meanings of the resource and the interests of the visitor that occurs among participants who have attended interpretive programs.

As indicated above, the concept of connections is defined in the IDP Module 101 as "linkages" or "relationships." These connections are " broad based and accessible both intellectually and emotionally“ (Larsen, 1997; NPS, 2000; NPS, 1997). The NPS

likens a connection as a linkage that visitors forge with the resources when they "develop an active stewardship ethic" (NPS, 2000).

\section{$\underline{\text { Study Design }}$}

The study incorporated mixed method design, including: purposeful sampling for visitor/interview participants (Patton, 1987; Miles \& Huberman, 1994), and interpreter selection, quasi-experimental pre-test/post-test design (Wiersma, 1995), focus group interviews (Krueger, 1994), and both quantitative and qualitative data analysis (Weber, 1990; Krueger, 1994; Miles \& Huberman, 1994; Henerson, Morris, \& Fitz-Gibbon, 1978). The study used both qualitative and quantitative methods and data analysis procedures to understand the meanings people attach to resources, places, events, and ideas at three $\mathrm{NCP}$-Central sites. A total of 182 visitors participated in 21 focus group 
interviews over six days of on-site interviews. Interviews were held on a consecutive Thursday, Friday, and Saturday in July 1998 (July 17-19) and during a consecutive Thursday, Friday, and Saturday in August 1998 (August 7-9). Interviews were conducted in the morning, afternoon, and evening to ensure that the sampling pool contained the widest possible range of visitor types.

The researchers chose to employ a pre-test/post-test design to examine the meanings that visitor attach to site resources and the connections that they made via interpretive programs. Some visitors who participated in the focus group interviews attended regularly scheduled interpretive programs while others did not. Focus groups conducted prior to visitor exposure to an on-site interpretive program sought to elicit information on (1) the meanings visitors attach to $\mathrm{NCP}-$ Central resources, and (2) the interest visitors have toward park resources and on-site interpretive programming. Focus groups conducted after visitor exposure to an on-site interpretive program sought to elicit information regarding (1) and (2) above, as well as (3) the connections visitors made between tangible resources, and intangible meanings, and universal concepts through the facilitation of ranger-led interpretive programs.

Six interpretive rangers assisted in the research process by interpreting park resources and history during nine scheduled presentations, explaining study goals to visitors, and recruiting interview participants. Five supervisory managers procured door prizes such as White House tickets, Holocaust Museum tickets, Washington Monument tickets, and Eastern National Park Bookstore gift certificates. They also provided the use of an NPS golf cart to researchers for on-site transportation. The park maintenance staff set up an outdoor canopy tent and tables and chairs by the reflecting pool in front of the Lincoln Memorial. Park maintenance staff also provided ice and electrical hook-ups. With the help from the maintenance staff, researchers were able to provide "icy-cold" refreshments and a shady place to sit down during the interviews, which proved to be two key enticements to recruit park visitors during hot summer days.

\section{$\underline{\text { Site Selection }}$}

Study sites were selected based on pre-determined selection criteria related to location, resources, programming, and staffing. NCP — Central was chosen due to its 
close proximity to the Stephen T. Mather Training Center and West Virginia University. NCP-Central contains a diversity of park resources and a wide range of potential visitor meanings (Map 1). The site has an active interpretive program and far exceeded the minimum selection requirement of four permanent interpreters on staff. Park rangers present several interpretive programs and talks throughout the day. They provide 10 to 30 minute interpretive talks on-site year round. During the summer months, they provide two-hour walking tours that focus on the history of the National Mall and other related themes (NPS, 1998a).

\section{Map 1. The Lincoln Memorial and Related Area}

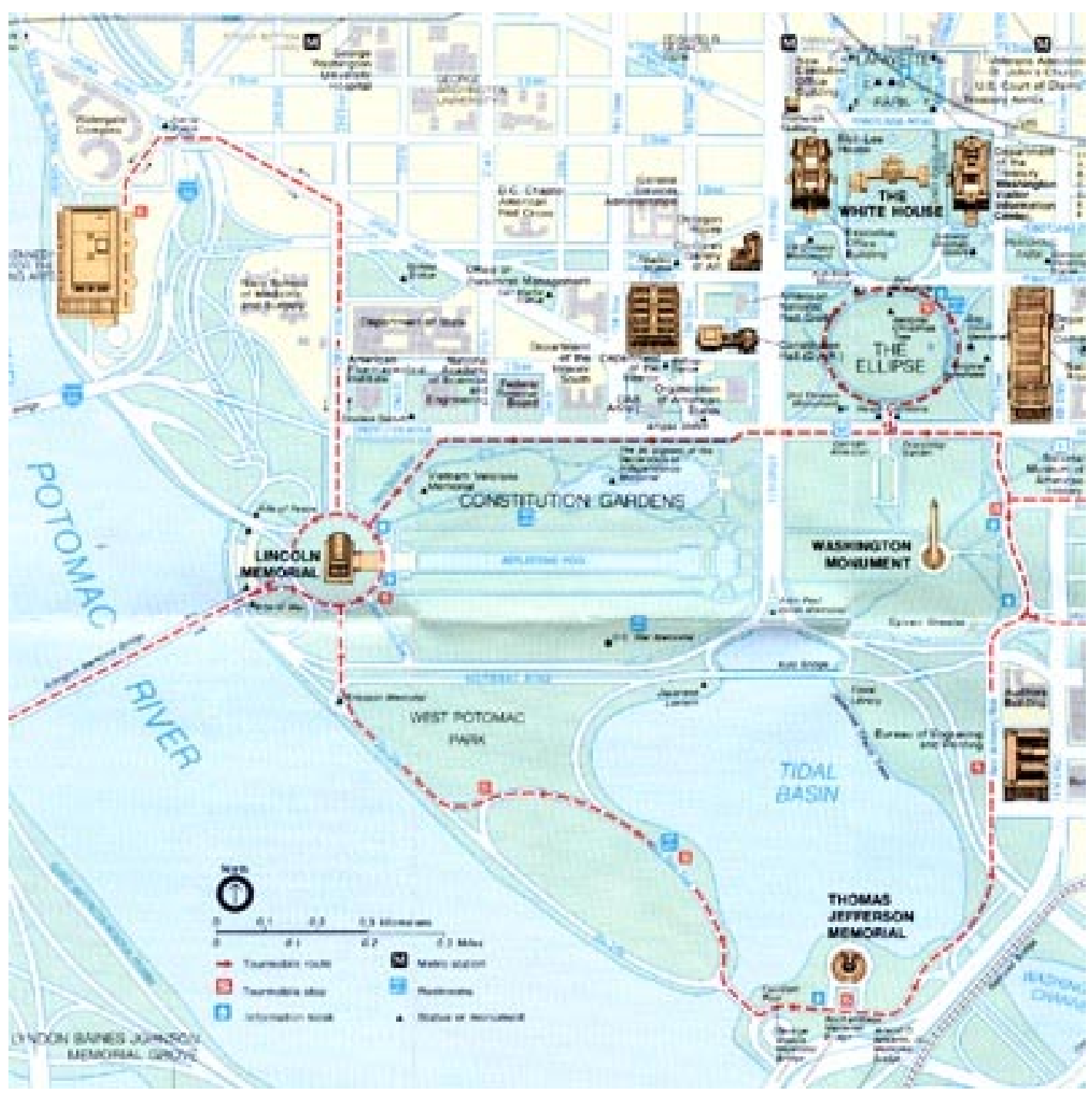


The three study sites at NCP-Central, including the Lincoln Memorial, the Vietnam Veterans Memorial, and the Korean War Veterans Memorial, represent diverse meanings to visitors (Map 2).

Map 2. The Triangle

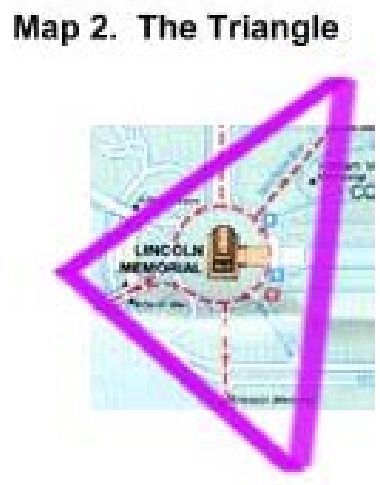

The Lincoln Memorial is located at one end of the National Mall and is the center of the "Triangle." The memorial is a tribute to President Lincoln and the nation he fought to preserve during the Civil War (1861-1865) (NPS, 1998b). Lincoln's leadership contributed to the final victory of the Union and the abolishment of slavery in the United States. The design and the components of the Lincoln Memorial make the memorial a tribute to the Union as much as a tribute to Lincoln himself (NPS, 1998b). Two of Lincoln's most important speeches are carved on the interior walls-the Gettysburg Address and the Second Inaugural Address. These texts help define the essential principles upon which this nation was founded. The plaza and the path along with the reflection pool in front of the Lincoln Memorial have another significance to the nationthe place of protest. Social movements have used the triangle and reflecting pool as a meeting ground to discuss issues such as race, civil rights, war and peace, and AIDS. 
The Vietnam Veterans Memorial is the most visited NPS site in Washington, DC (NPS, 1998c). The Vietnam Veterans Memorial serves as a testament to the sacrifice of American military personnel during one of the nation's least popular wars. A journalist from the New York Times described the memorial as "a hallowed site of a spiritual dimension that transforms it into something like a sacred shrine, where pilgrims come and devotions are paid" (Niebuhr, 1994, November 11th). Palmer (1998) describes it as a sacred and silent ritual place of healing. Memories of the Vietnam War and the image of the black granite wall live vividly in the minds of Americans.

The Korean War Veterans Memorial is dedicated to all those who served during The Korean War (1950-1954), the first major conflict during the Cold War. For the families and friends of the men and women who never returned, the Korean War is never a "forgotten war." The returning veterans were the first American veterans not to receive a heroes' welcome in recognition of their hardships and their fight for freedom (NPS, 1998a). Being one of the newest memorials in the National Mall (dedicated in 1995), the memorial draws visitors who want to learn about the less-popular Korean War history and commemorate those who served.

\section{Focus Group Interviews}

The study used focus group interviews to elicit and record visitor responses. Krueger (1994) identified six characteristics related to focus group interviews: "people, assembled in a series of groups, [who] possess certain characteristics, provide data, of a qualitative nature, and in a focused discussion" (p. 16). He also asserts that "focus groups are valid if they are used carefully for a problem that is suitable for focus group inquiry" (p. 31). One of the many strengths of focus group interviews is collecting data in a more natural setting. Focus group interviews are especially suited to collect empirical material such as personal experiences, introspections, life stories, group interactions, and specific meanings in individuals' lives.

The in-depth interview moderator was Dr. Theresa L. Wang and the researcher participated as the assistant moderator. The study recorded participant responses to openended questions. Sample interview questions include from the following:

- What drew you to the site today? 
- What do these sites teach us?

- When you look at the statue of Lincoln, what thoughts go through in your mind?

- What would you tell the younger generations about this place?

- When you are here, do you have a sense of interacting with history?

- Is it different learning history here compared to the school classroom? If so, in what way?

- If you were a ranger, what would you tell your audience?

- (For groups that had attended a ranger-led program, participants were asked one additional question.) Did the ranger's talk help you think about this place in a new way?

Sometimes researchers probed for more responses. Babbie (1995) explains that probes are frequently used in eliciting responses to open-ended questions. For example, in response to a question about "What do these sites teach us?", the participant might simply reply, "Freedom" or "War sucks." Researchers used probes such as "In what ways?" or sometimes they were just silent, waiting for more responses. Among the 21 focus group interviews, all were conducted in English except one was conducted in Chinese and later translated into English. Focus group interviews were tape recorded and transcribed verbatim. Following each focus group interview, participants were asked to fill out a one-page demographic survey and answer four questions on the purpose of their trip, the number of previous visits to the site, the number of interpretive talks attended, and the length of their stay on site.

\section{Data Analysis}

The analysis of interview transcripts was accomplished by a process which combined (1) hand coding the data, (2) sorting the data into related categories, (3) analyzing categories to identify recurring patterns and themes, (4) clustering and specifying the range of visitor meanings, interests, and connections, (5) making contrasts and comparisons, (6) subsuming particulars into generals when appropriate to do so, and (7) ensuring conceptual coherence (Weber, 1990; Miles \& Huberman, 1994). In addition 
to hand coding and sorting the data, researchers also conducted a computerized keyword frequency analysis.

Weber (1990) suggests that "the most frequently appearing words reflect [participants'] greatest concerns" (p. 51). One potential outcome of this finding is that researchers may examine participants' top 10 most frequently used words to identify the similarity and differences of prioritized concepts among the participant groups (p. 51). By calculating frequently repeated words in the data, researchers were able to identify the greatest concerns and the special interests of the participants (Weber, 1990; Krueger, 1994). Researchers used a word processing software to generate the Keyword Frequency Lists. Researchers identified a list of key concepts and omitted uninteresting words such as $a$ and the, forms of the verb to be, and subjects such as $I$ and we. To capture the essential meanings being expressed, the researchers also combined the verb/noun/adjective forms of words such as appreciate (d), appreciation, and appreciative as well as the single and plural of nouns such as meaning and meanings.

The study design aimed to identify the meanings visitors attach to three NCP sites and to examine intellectual and emotional connections that visitors made through interpretive programs. Previous interpretive research has not focused on the importance of interpreters' knowledge of the audience and has not measured the extent of visitor intellectual and emotional connections to the meanings of the resources. The methods used in this study allowed the researcher to examine these two critical areas if scholarly inquiry.

\section{$\underline{\text { Research Limitations }}$}

The nature of the qualitative approach makes the identification and measurement of a facilitated "connection" a challenge to the researchers. First of all, existing literature in psychology, communication, education, and interpretation have very limited relevant sources. Some studies vaguely describe the phenomenon of a "connection." However, they do not clearly define the range, the depth, and the length of a connection with a place or resource once it is made. This lack of understanding hinders the success of promoting resource stewardship through a facilitated process of interpretation. Secondly, labeling typed of connection is difficult and inconclusive. The IDP requires the 
interpreter to facilitate both emotional and intellectual connections. Sometimes, a person's emotional connection is based on a comprehensive understanding of the resource. Without a lot of "information," this person may feel "disconnected." At the same time, for those who just need very little information to gain an emotional connection, they may become bored with an overemphasis on facts, narrative or chronology. A normative approach to understanding the process of facilitating connections may be able to solve this dilemma. A normative approach could help interpreters better understand how many intellectual and emotional "hooks" are enough to facilitate a quality interpretive experience. The following are other limitations on this research:

- The interview location had both advantages and disadvantages. Being so close to the Triangle, the researchers were more likely to recruit park visitors to participate in the interviews. During the interview process, participants can actually see the Lincoln Memorial in front of them which helped them described their meanings, values, and experiences. The disadvantage of the location is that it is on a high-traffic commercial aircraft route. Approximately every five minutes, there was a take-off or landing. The loud noise made it hard for the group to listen and the tape recorder to record the dialogue.

- The nature of a focus group interview makes it hard to cross-tabulate and compare visitor meanings by different demographic variables. The group dialogue was taped and transcribed as a group. Many times participants talked at once. Even though a background information sheet did record participant demographics such as gender, age, geographic region, numbers of visit on site, etc., the study did not incorporate additional techniques to determine who said what in a ten-page long transcript. However, the researchers tried to use the observation method to meet this challenge. The strength of the focus group method is also the disadvantage of the method. 
- The hand-coding content analysis method is extremely time-consuming. It has a high face validity, but credibility may suffer if researchers overstate their results. 


\section{Chapter Four}

\section{Results}

\section{$\underline{\text { Participant Demographics }}$}

During six days in the summer of 1998 (three days in July and three days in August), researchers interviewed a total of 182 visitors. Visitors were divided into 21 focus groups-12 groups had not attended an interpretive program, whereas nine groups had attended an interpretive program. The gender distribution of participants was about equal with 53 percent female and 47 percent male visitors. The participants were from diverse geographic regions, 13 percent were from Washington, DC, Virginia, and Maryland; 60 percent were from states east of the Mississippi River; 15 percent were from the states west of the Mississippi River; and 12 percent were international visitors (Figure 1). Interviewees represent a wide range of age groups (Figure 2). The majority of visitors were in the $26-40$ year old age range (30\%) and the $41-55$ year old age range $(25 \%)$. The researchers were also able to interview a number of visitors under age $13(14 \%)$. Almost forty-four percent of the interviewees were first-time visitors to the site, although $17 \%$ of the interviewees had visited NCP - Central five or more times (Figure 3). Through observation, the participants represent diverse backgrounds including African (4\%), Hispanic (2\%), Asian (4\%), and Anglo (90\%) descent (Figure 4). 
Figure 1. NCP-Central Visitor Focus Group Interview Participants Geographic Region

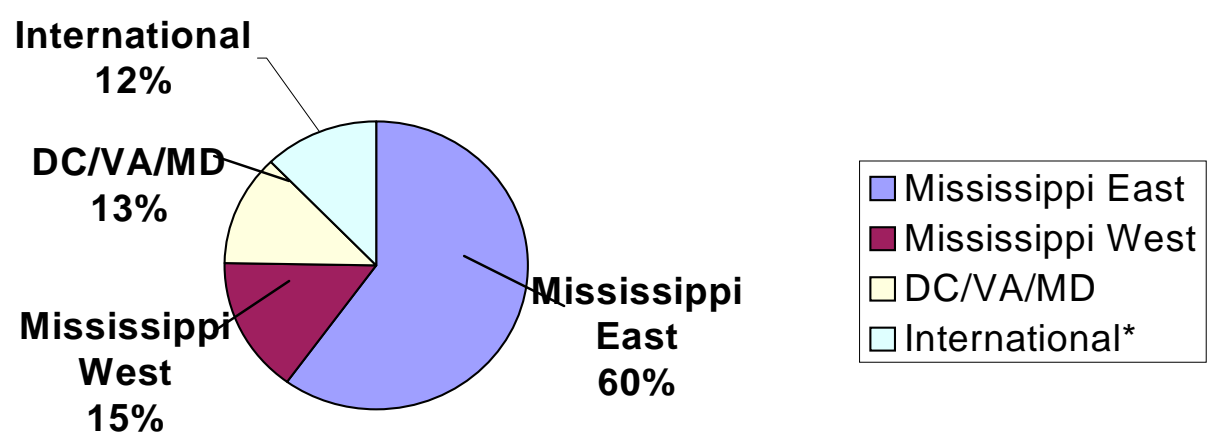

Figure 2. NCP—Central Visitor Focus Group Interview Participants Age Range

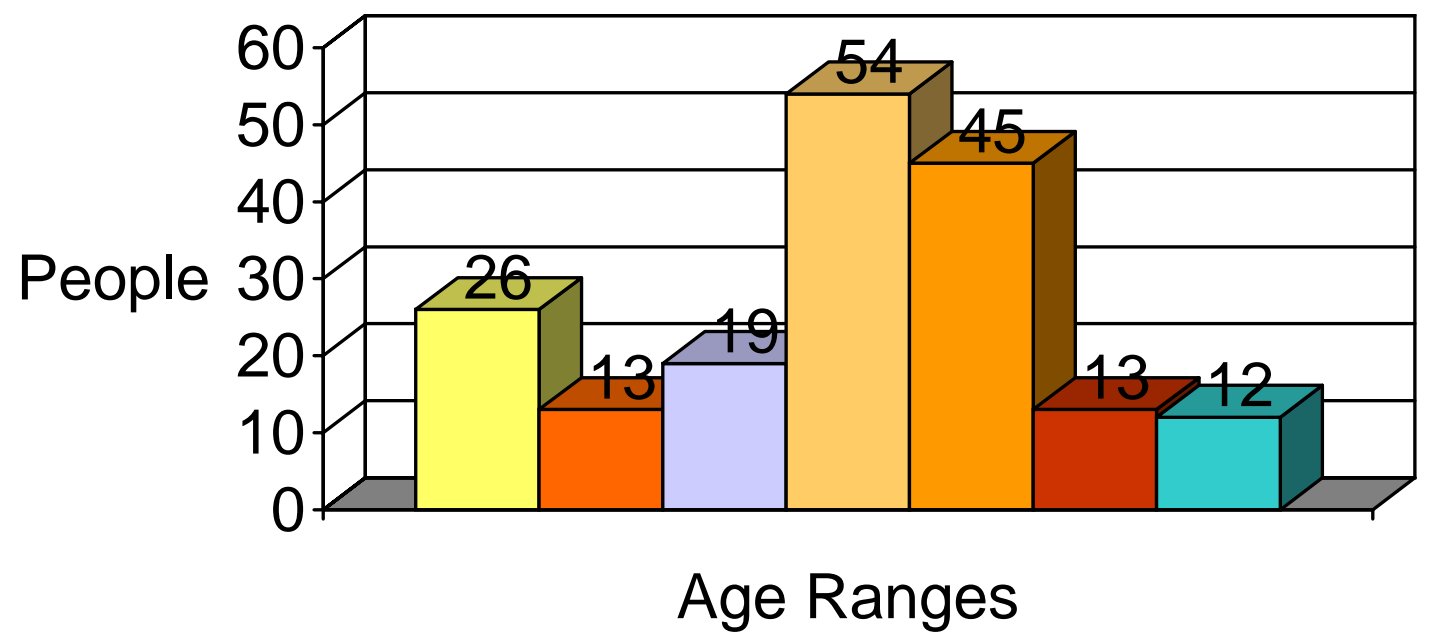

$\square<13 \square 13-18 \square$ 19-25 $\square 26-40 \square$ 41-55 $\square 56-65 \square>65$ 
Figure 3. NCP—Central Visitor Focus Group Interview Participants' Number of Visits to Site

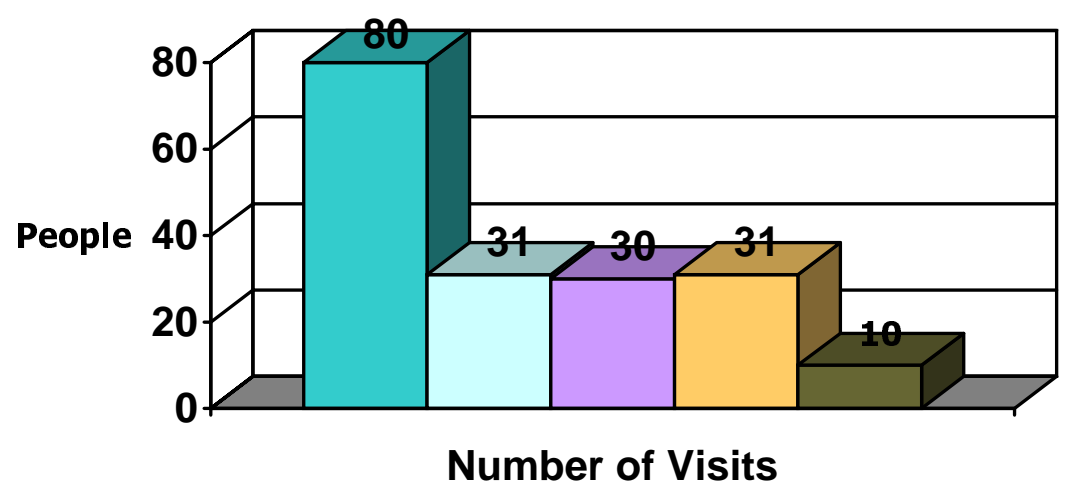

$\square 1$ Visit $\square 2$ Visits $\square 3$ to 4 Visits $\square 5+$ Visits $\square$ Unknown

Figure 4. NCP - Central Visitor Focus Group Interview Participants Ethnic Background $\square$ Anglo $\square$ African $\square$ Hispanic $\square$ Asian

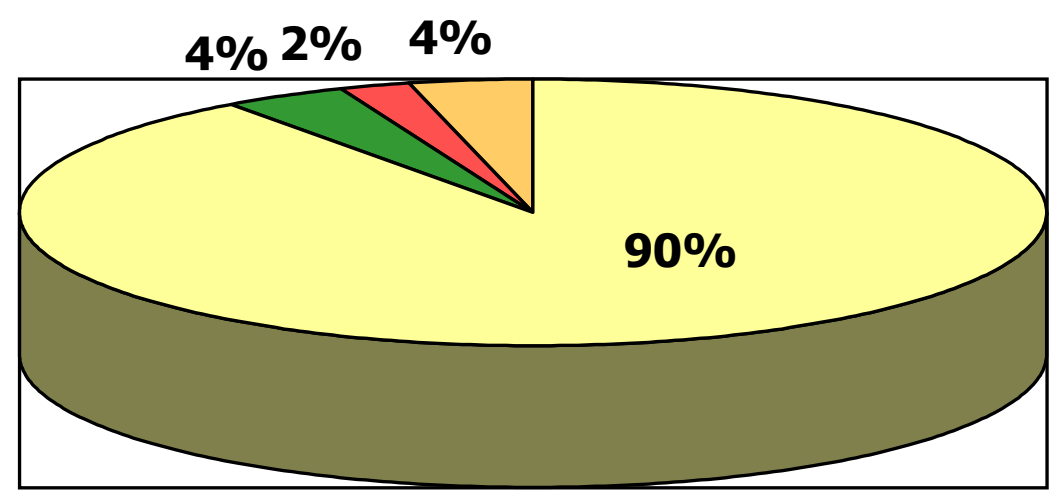


A comparison of the demographics of this study's sample population with a visitor study done by Littlejohn and Hoffman (1999) that was also conducted during the summer of 1998 at NCP_Central at a similar study area. The Littlejohn and Hoffman study covered three additional sites including the Washington Monument, Franklin D. Roosevelt Memorial, and Jefferson Memorial. Our results suggest that the participant demographics were very similar between the two studies—even though Littlejohn and Hoffman surveyed a total of 2,720 visitors. The similarity in participant demographics suggested that the present study obtained a fairly representative cross-section of on-site visitors.

To be more specific, visitors from the United States represented 30 states and the District of Columbia (DC) in this study. Almost seventy-six percent of the total visitors came from states other than those surrounding the studying site (Virginia, Maryland, and DC). Only one percent of the total visitors were DC residents. Sixty percent of visitors were from the states east of Mississippi River and 17\% of visitors came from states west of the Mississippi River. Littlejohn and Hoffman found more than $62 \%$ of the visitors were from Mississippi east and more than $23 \%$ of the visitors came from Mississippi West.

In this study, international visitors $(\mathrm{N}=24)$ comprised a total of $12 \%$ of the interviewees. International visitors were from England $(\mathrm{N}=7)$, Canada $(\mathrm{N}=4)$, Israel $(\mathrm{N}=3)$ and Mexico $(\mathrm{N}=3)$, China $(\mathrm{N}=2)$, France $(\mathrm{N}=2)$, Nigeria $(\mathrm{N}=2)$, and Germany $(\mathrm{N}=1)$. Littlejohn and Hoffman found that a total of $7 \%$ of their sample were comprised of international visitors ( $\mathrm{N}=207)$ who came from Germany (14\%), England (9\%), India $(5 \%)$ and other countries (72\%). Both studies found the same results in terms of where visitors live: the majority of the visitors came from states east of the Mississippi River, then Mississippi west visitors, then the three surrounding states, and then international visitors.

The age group of the majority of interviewees approximately matches the Littlejohn and Hoffman study. In our sample, $55 \%$ of interviewees were between the ages of 26-55. Littlejohn and Hoffman found that participant age groups were concentrated in two areas, $41 \%$ for the $31-50$ year old age range and $28 \%$ for the 15 or younger year old age range. 
In this study, forty-four percent of interviewees were first-time visitors compared with $56 \%$ first-time visitors in the Littlejohn and Hoffman study. Seventeen percent of the interviewees had made five or more trips to the Triangle in the past compared with $8 \%$ of the visitors in the Littlejohn and Hoffman study. One notable difference between the two study populations is that the present study included more participants who had visited the site five or more times (17\%) compared to Littlejohn \& Hoffman who found that $8 \%$ of their sample had visited the site five or more times. Similarly, $44 \%$ of participants in the present study were first-time visitors to the site, compared to $56 \%$ firsttime visitors in the Littlejohn \& Hoffman study. Although the relative proportions still hold, these differences suggest that repeat visitors may have been more inclined to participate in an on-site focus group interview, and first-time visitors may have been less inclined to do so. However, the close demographic correlation between the two studies across all information categories suggests that the present study obtained a fairly representative sample of on-site visitors.

Besides the fact that the Littlejohn and Hoffman study did not have information on visitor ethnic background and gender, the similarity in participant demographics suggests that a fairly representative cross-section of on-site visitors was obtained in the present study in terms of geographic origin, age ranges, and number of site visits.

\section{Word Frequencies}

Some words or phrases were mentioned frequently by visitors because the words represent place names or help visitors orient themselves to a site. Other frequently mentioned words may reflect visitors' greatest concerns or interests (Weber, 1990). Some concepts may be deemed by participants to be of considerable importance, yet a specific word or phrase associated with that concept may occur with minimal frequency. This is often the case when key concepts can be expressed or interpreted in multiple ways.

The results of the keywords and concepts frequency analysis (Table 5) suggest that $\operatorname{war}(\mathrm{N}=281)$ is at the center of the meanings that visitors attach to the sites, although the frequency of visitor's use of the term "war" stems in part from its inclusion in the names of two of the three sites at the Triangle (i.e. Korean Veterans Memorial, Vietnam 
Veterans Memorial). Topics related to Lincoln ( $\mathrm{N}=240$ ) were also frequently mentioned. Memorial $(\mathrm{N}=222)$ and History $(\mathrm{N}=183)$ were the third and forth most common word used during the interviews. Story $(\mathrm{N}=182)$ as it relates to the people, events and buildings, interested most visitors; and story-telling was expressed as the most preferred way to gain understanding and insight into the park's heritage resources. Visitors also viewed the resources as symbols of the country $(\mathrm{N}=138)$ of the United States of America. Park rangers $(\mathrm{N}=117)$ play an important role in providing quality visitor experiences and the word ranger was frequently mentioned. Other frequently appearing words such as interest $(\mathrm{N}=116)$, learn $(\mathrm{N}=94)$, monument $(\mathrm{N}=91)$, Washington $(\mathrm{N}=82)$, teach $(\mathrm{N}=70)$, American $(\mathrm{N}=65)$, freedom $(\mathrm{N}=43)$, symbol $(\mathrm{N}=35)$, and emotion $(\mathrm{N}=34)$ also suggest that visitors bring a range of preestablished emotional and symbolic meanings to the sites: visitors sense that these sites represent the nation's ideals and identity, the past and the hoped for future. Visitors consider the ideas of learning $(\mathrm{N}=94)$ and teaching $(\mathrm{N}=70)$ history and current issues to be a meaningful part of their visit to these memorials and monuments. Even so, many visitors emphasized that the learning experience in the Triangle was different than the usual history education held in school classrooms. With regards to frequency and extensiveness, some words were less frequently mentioned than might have been expected. These words are patriotism $(\mathrm{N}=8)$, democracy $(\mathrm{N}=5)$, and identity $(\mathrm{N}=1)$. Many visitors, however, did experience a sense of patriotism after exploring memorials and monuments. These visitors might refer to Washington, DC as the "most important city in the world" or express their view that "everyone has to come here at least once in their lifetime" as a way to express their passion and patriotism. Or, visitors may have expressed a sense of gratitude for the patriotism and sacrifice of those who served.

The fact that some words appeared less frequently than expected does not suggest the absence of these concepts or even a diminished sense of their importance among participants. Rather, a key concept may have been alluded to or implied through the use of other words or phrases (Weber, 1990). For instance, democracy was only referred to five times and stewardship was never mentioned during all of the focus group interviews. However, when participants mentioned "freedom," they often reiterated that "freedom is 
not free," which implies some level of "democratic participation or civic action" as essential to establishing and maintaining freedom.

The frequency analysis revealed the intensity and diversity of the emotional and intellectual bonds visitors made while visiting the Triangle. Many participants expressed their desire to "know more" about Lincoln or the Korean War, which they may have overlooked in the past. They told the researchers that they wanted to keep "coming back." Some visitors also showed an intention to discover the current management challenges the memorials face. If the stewardship of park resources can be defined as care about park resources so that one comes to care for park resources, then even though participants never mentioned the word "stewardship" directly during the interview, a form of stewardship did emerge through attending the interpretive programs at NCPCentral. Since resources at the triangle represent many of the ideals upon which the nation was founded "stewardship" on this context may be equated with civic engagement and participation in our democratic society. 
Table 5. Keyword Frequencies

\begin{tabular}{|c|c|c|}
\hline \multicolumn{3}{|c|}{ Pre 1-12 } \\
\hline Rank & Keyword & Total \\
\hline 1 & War & 175 \\
\hline 2 & Memorial & 131 \\
\hline 3 & Lincoln & 108 \\
\hline 4 & History & 89 \\
\hline 5 & Story & 83 \\
\hline 6 & Country & 82 \\
\hline 7 & Ranger & 68 \\
\hline 8 & learn & 67 \\
\hline 9 & Interest & 65 \\
\hline 10 & Monument & 60 \\
\hline 11 & Teach & $\overline{43}$ \\
\hline 12 & Washington & 41 \\
\hline 13 & Remember & 37 \\
\hline 14 & American & 35 \\
\hline 14 & Aware & 35 \\
\hline 16 & Lincoln Memorial & 33 \\
\hline 16 & Meaning & 32 \\
\hline 18 & Civil War & 30 \\
\hline 18 & Connection & 30 \\
\hline 18 & Important & 30 \\
\hline 18 & Washington, D.C. & 30 \\
\hline 22 & F.D. Roosevelt & 26 \\
\hline 22 & Veteran & 26 \\
\hline 24 & Experience & 25 \\
\hline 25 & Korean War & 24 \\
\hline 26 & Emotionnal & 23 \\
\hline 27 & Freedom & 22 \\
\hline 27 & Jefferson Memorial & 22 \\
\hline 27 & Vietnam War & 22 \\
\hline 30 & Children & 19 \\
\hline 30 & Serve & 19 \\
\hline 32 & President & 18 \\
\hline 32 & Symbol & 18 \\
\hline 32 & The Mall & 18 \\
\hline 35 & The Capitol & 17 \\
\hline 36 & home & 16 \\
\hline 37 & Washington Monument & 15 \\
\hline 38 & Conflict & 13 \\
\hline 38 & generation & 13 \\
\hline 38 & Jefferson & 13 \\
\hline 41 & Martin Luther King, Jr. & $\overline{12}$ \\
\hline 41 & Pride & 12 \\
\hline 43 & Union & 11 \\
\hline 43 & World & 11 \\
\hline 45 & Speech & 10 \\
\hline 46 & Government & 8 \\
\hline 47 & unity & 7 \\
\hline 48 & commemorate & 6 \\
\hline 48 & Honor & 6 \\
\hline 48 & International & 6 \\
\hline 51 & Appreciate & 5 \\
\hline 51 & city & 5 \\
\hline 51 & Forrest Gump & 5 \\
\hline 51 & Patriotism & 5 \\
\hline 51 & Peace & 5 \\
\hline 51 & Slavery & 5 \\
\hline 57 & Culture & 4 \\
\hline 57 & Sacrifice & 4 \\
\hline 59 & Come Alive & 3 \\
\hline 59 & Education & 3 \\
\hline 59 & Interaction & 3 \\
\hline 59 & Language & 3 \\
\hline 59 & Powerful & 3 \\
\hline 64 & Civil right & 2 \\
\hline 64 & community & 2 \\
\hline 64 & Future & 2 \\
\hline 64 & protests & 2 \\
\hline 68 & Architecture & 1 \\
\hline 68 & Democracy & 1 \\
\hline 68 & Icon & 1 \\
\hline 68 & Relevance & 1 \\
\hline 72 & demonstrations & 0 \\
\hline 72 & Identity & 0 \\
\hline 72 & Politics & 0 \\
\hline 72 & Preservation & 0 \\
\hline Total & & $\overline{1827}$ \\
\hline
\end{tabular}

\begin{tabular}{|c|c|c|}
\hline \multicolumn{3}{|c|}{ Post 1-9 } \\
\hline Rank & Keyword & Total \\
\hline 1 & Lincoln & 132 \\
\hline 2 & War & 106 \\
\hline 3 & Story & 99 \\
\hline 4 & History & 94 \\
\hline 5 & Memorial & 91 \\
\hline 6 & Country & 56 \\
\hline 7 & Interest & 51 \\
\hline 8 & Ranger & 49 \\
\hline 9 & Washington & 41 \\
\hline 10 & Lincoln Memorial & 37 \\
\hline 11 & Washington, D.C. & 36 \\
\hline 12 & children & 35 \\
\hline 13 & Monument & 31 \\
\hline 14 & American & 30 \\
\hline 14 & Civil War & 30 \\
\hline 16 & learn & 27 \\
\hline 16 & Teach & 27 \\
\hline 18 & Remember & 23 \\
\hline 19 & Freedom & 21 \\
\hline 19 & The Mall & 21 \\
\hline 21 & World & 19 \\
\hline 22 & Symbol & 17 \\
\hline 23 & Korean War & 16 \\
\hline 23 & President & 16 \\
\hline 23 & Serve & 16 \\
\hline 26 & Important & 14 \\
\hline 26 & Jefferson & 14 \\
\hline 26 & Meaning & 14 \\
\hline 26 & Vietnam War & 14 \\
\hline 30 & Language & 13 \\
\hline 31 & Interaction & 12 \\
\hline 31 & Slavery & 12 \\
\hline 33 & Emotional & 11 \\
\hline 34 & Conflict & 9 \\
\hline 34 & Experience & 9 \\
\hline 34 & Government & 9 \\
\hline 34 & Washington Monument & 9 \\
\hline 38 & city & 8 \\
\hline 38 & Generation & 8 \\
\hline 40 & powerful & 7 \\
\hline 40 & Sacrifice & 7 \\
\hline 40 & unity & 7 \\
\hline 43 & F.D. Roosevelt & 6 \\
\hline 43 & Speech & 6 \\
\hline 46 & Appreciatation & 5 \\
\hline 46 & Veteran & 5 \\
\hline 49 & Architecture & 4 \\
\hline 49 & Democracy & 4 \\
\hline 49 & Icon & 4 \\
\hline 49 & Peace & 4 \\
\hline 51 & Come Alive & 3 \\
\hline 51 & Connection & 3 \\
\hline 51 & Education & 3 \\
\hline 51 & Jefferson Memorial & 3 \\
\hline 51 & Patriotism & 3 \\
\hline 51 & The Capitol & 3 \\
\hline 57 & Civil right & 2 \\
\hline 57 & home & 2 \\
\hline 57 & Honor & 2 \\
\hline 57 & Pride & 2 \\
\hline 61 & aware & 1 \\
\hline 61 & community & 1 \\
\hline 61 & Culture & 1 \\
\hline 61 & Forrest Gump & 1 \\
\hline 61 & Identity & 1 \\
\hline 61 & International & 1 \\
\hline 61 & Preservation & 1 \\
\hline 61 & Union & 1 \\
\hline 69 & commemorate & 0 \\
\hline 69 & demonstrations & 0 \\
\hline 69 & Future & 0 \\
\hline 69 & Martin Luther King, Jr. & 0 \\
\hline 69 & Politics & 0 \\
\hline 69 & protests & 0 \\
\hline 69 & relevant & 0 \\
\hline Total & & 1370 \\
\hline
\end{tabular}

\begin{tabular}{clr} 
Rank & Keyword & Total \\
\hline 1 & War & $\mathbf{2 8 1}$ \\
2 & Lincoln & $\mathbf{2 4 0}$ \\
3 & Memorial & $\mathbf{2 2 2}$ \\
4 & History & $\mathbf{1 8 3}$ \\
5 & Story & $\mathbf{1 8 2}$ \\
6 & Country & $\mathbf{1 3 8}$ \\
7 & Ranger & $\mathbf{1 1 7}$ \\
8 & Interest & $\mathbf{1 1 6}$
\end{tabular}

8 Interest

\begin{tabular}{cll}
10 & Monument & $\mathbf{9 1}$ \\
\hline 11 & Washington & $\mathbf{8 2}$
\end{tabular}

12 Lincoln Memorial $\quad \mathbf{7 0}$

12 Teach

14 Washington, D.C. $\quad 66$

15 American 65

16 Civil War 60

16 Remember $\quad 60$

18 Children 54

19 Meaning 46

20 Important 44

21 Freedom 43

22 Korean War 40

23 The Mall 39

24 Aware 36

24 Vietnam War 36

26 Serve 35

26 Symbol 35

28 Emotionnal 34

28 Experience 34

28 President 34

31 Connection 33

32 F.D.Roosevelt 32

33 Veteran 31

34 World 30

35 Jefferson 27

36 Jefferson Memorial 25

37 Washington Monument 24

38 Conflict 22

39 generation 21

\begin{tabular}{lll}
40 & The Capitol & 20 \\
\hline 41 & Home & 18
\end{tabular}

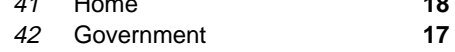

42 Slavery 17

44 Language 16

44 Speech 16

46 Interaction 15

47 Pride 14

47 unity 14

49 city 13

50 Martin Luther King, Jr. 12

50 Union

52 Sacrifice

53 Appreciate

53 Powerful

55 Peace

56 Honor

57 Patriotism

58 Internationa

59 Come Alive

59 commemorate

59 Education

59 Forrest Gump

62 Architecture

62 Culture

62 Democracy

62 Icon

67 Civil right

68 community

69 Future

69 protests

71 Identity

71 Preservation

71 Relevance

74 demonstrations

74 Politics 


\section{A Summary of Participant Responses to the Interview Questions}

The researcher summarized participant responses to each of the eight questions (seven for the pre-groups and eight for the post groups) asked during the focus group interview. Hand-coding was used to analyze participant responses.

Question 1: "What drew to the site today?"

Summary of Participant Responses:

Both pre and post participants described a variety of reasons regarding why they chose to visit Washington, DC and the Triangle. These motivations include: the love of and interest in history, an admiration for President Lincoln, companionship with family or other social groups, a sense of personal connection with the Vietnam or Korean War and the Memorials, a desire to "show" these places to out-of-town or international guests, being in the vicinity, a desire to observe the hub of the democratic system and government agencies, and the desire to see the "landmarks" or the "must visit" places in Washington, DC - especially for international visitors. Some of the young participants, especially children, voiced their affection toward President Lincoln directly. Ss one child said, "Because I want to see Mr. Lincoln” (Pre 7, p. 1). Whole families visited Washington, DC to provide children with these significant experiences. There was one significant difference among the pre and post groups. Compared with the pre groups, the post program participants were more likely to use the exact "place names" and "historic character names" when explaining what drew them to the site.

\section{Question 2: "What do these sites teach us?"}

Summary of Participant Responses:

Both pre and post participants were able to address a range of "universal concepts" when responding to "What do these sites teach us?" These key concepts include: a sense of connection to the past, a connection with national history, pride, liberty, sacrifice, unity, the heritage of democratic freedom, the issue of war and peace, and "a sense of what this country is about" (Woman, Pre 11, p. 3). Several post program participants mentioned additional meanings such as: awareness of "the dark period" in the U.S. history (Woman, Post 6, p. 3). These post group participants were more likely to 
refer to their on-site experiences, refer back to the key points of the ranger program that they had just attended, connect tangible resources with symbolic meanings, and form personal meanings for the site resources. For example, in response to this question, one participant said, "The Lincoln Memorial..., he is obviously a very dynamic person. He went through very tough times in the nation's history. I just wanted to be there and read the Gettysburg Address and the Second Inaugural Address. You do get a special feeling, especially listening to the ranger's talk. He is very good, very passionate" (Man, Post 8, p. 2). The story of what Lincoln went through personally and how he led people through difficult times in the nation's history were two of the main points in the interpretive programs delivered at the Lincoln Memorial. The ranger used Lincoln's two addresses to help visitors connect with the meanings of President Lincoln's life and the Lincoln Memorial (Figure 5).

Figure 5. A Ranger Linking a Tangible Resource with its Intangible Meanings at the Lincoln Memorial

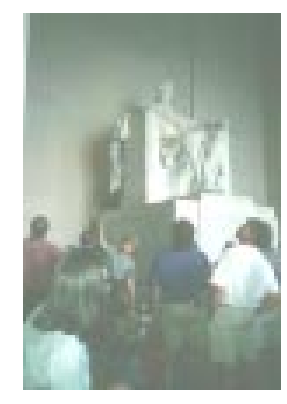

Question 3: "When you look at the statue of Lincoln, what thoughts go through in your mind?"

Summary of Participant Responses:

Participants had similar responses toward the third question were similar to their responses to the second question. Sometimes, participants would only say one word (e.g. "Freedom" or "History") in response to question two about what the Triangle teaches people. The researchers asked the third question to draw out additional meanings attached to the Lincoln Memorial. Again, the post groups seem to "recall" or "shadow" 
(Ham, 1992) the story or topics presented in the interpretive program to respond to this question.

Question 4: "What would you tell the younger generations about this place?" Summary of Participant Responses:

Both the pre and post participants responded that they enjoy telling the younger generations about the Triangle. They likened the experience to telling stories or performing oral history. They saw it as a great opportunity to orally "pass on experiences and information [from] person to person" (Woman, Pre 2, p. 5). Participants identified several topics that they felt were worth passing on to younger generations: U.S. history, the story of President Lincoln, the symbolism of the memorials, and the role of government in society.

Question 5: "When you are here, do you have a sense of interacting with history?" Summary of Participant Responses:

All but one of the participants said that they did have a sense of interacting with history at the Triangle. A math teacher from South Dakota who hadn't attended an interpretive program when interviewed said that he was "disconnected" with the past and "never particularly cared for it" (Man, Pre 10, p. 5). He felt that he needed more historical knowledge to be connected. Among other positive interactions with the history on-site, participants described various cognitive and affective on-site experiences. The cognitive matters include: "[it brought] back everything I learned in school” (Man, Pre 11, p. 5), "I learned about the Korean War which the history classes weren't able to cover" (Man, Pre 6, p. 6), and "I realized the size of the memorials and the importance/meanings behind it" (Woman, Post 6, p. 5). Descriptions of affective processes included such comments as: "Coming here is like having a tactile sensation of enjoying history" (Man, Pre 2, p. 8), "I cry every time I came to the Vietnam Memorial. I can’t help it" (Man, Pre 5, p. 2), or simply "When I saw all these things down here, and I am like 'Oh, my God!’” (Woman, Pre 9, p. 3). 
Question 6: "Is it different learning history here compared to the school classroom? If so, in what way?"

Summary of Participant Responses:

Both pre and post group participants agreed that it was very different learning history on site compared with learning the same material in school classrooms. Many of the school-aged participants highlighted that the whole experience was "interesting," "fun," and being physically there helped them remember more at the Triangle.

Participants explained how past knowledge was recalled, new identities, meanings, and images were captured, and everything was transformed and stored in their minds in the form of visual memories. These memories usually last a lifetime, and sometimes even cross generations. The whole process can be illustrated by the following responses. First of all, participants recalled the past knowledge as this child said, "Everything that you learn and everything that you know comes together here" (Child, Pre 6, p. 10). Secondly participants captured new identities, meanings, and images when seeing the memorials in front of them as this child said, "In school, there are the textbooks. There is no connection. ... By coming here, you can actually make a connection of Lincoln and to the monument here" (Child, Pre 7, p. 8). Thirdly participants transformed and stored these messages to visual memories as this child mentioned, "You can really have a visual memory, more than just memorizing" (Child, Post 5, p. 5). And finally participants said that these memories lasted a long time as this woman lighted, "I remember being a little girl with my parents. And every time I read anything about him [President Lincoln] or learned anything about him, I pictured the memorial, the statue. Then I brought my children back and I felt a little more in charge. And for myself I have more understanding of it. It's good to get that feeling. You are supposed to be inspired by something powerful and by the ideas" (Woman, Post 4, p. 12).

Question 7: "If you were a ranger, what would you tell people?" Summary of Participant Responses:

Both pre and post group participants had a clear sense of what to include and what $n o t$ to include in a program if they were a ranger. Many participants explained that they would emphasize the following elements: (1) tell a story or present interesting trivia, (2) 
emphasize more the why than what, (3) present a holistic picture, (4) be inspirational and relevant, and (5) be interactive. The topics or key points that they would like to address include, the strength and character of President Lincoln, freedom, unity, and sacrifice. Participants also suggested connecting these topics with current civil, democratic, or management issues. Several participants highlighted the things that they would hope to avoid if they were to give a program. Things to avoid include: not to overwhelm people, not to bombard the audience with numerous facts, not to be boring.

Question 8: "Did the ranger's talk help you think about this in a new way?" Summary of Participant Responses:

This question was asked only to those who had attended an interpretive program. Most of the participants agreed that the interpretive program did help them form new meanings for the Triangle. Several participants thought that interpreters "reminded" and "reiterated" some perspectives that they had prior to the visit. Many of them expressed that interpreters also engaged visitors by "sharing," "pointing [things] out," "making us think a bit more huge," and "helping to add perspective" to the meanings and values of the memorials. Others pointed out that programs facilitated multiple layers of meanings, and did not just deliver one overall statement of the meanings of the resource by saying something like "what the Lincoln Memorial really represents is..." The overall responses to the interpretive programs were "good," "great," "wonderful," "impressive," and "amazing." Several people thought that the programs were "deep" and "complex." A few participants said that they were "lucky" to attend the program and that they "love to learn more about" the subjects.

\section{Themes}

Themes are commonly used in reporting focus group interview results (Masberg, 1996; Masberg \& Silverman, 1996; Galliano \& Loeffler, 1999). Krueger (1994) suggests researchers to address a small number of themes or key points with cited quotes from the interview. These statements are not limited to specific questions but often tie together themes that bridge several questions, if not the entire discussion (p. 166). Four themes emerged during this data analysis process. Responding to research questions seeking to 
identify and understand visitor meanings of the resource, place attachment, values, and perspectives, the data reveal a spectrum of meanings that visitors attach to the site, a range of visitor interests related to interpretive programming, and the connections that visitors made as a result of exposure to an on-site interpretive program. These four themes reflect: (1) a sense of spiritual connection with the ideas of the nation, (2) the strength, character, and aspiration of Lincoln, (3) the elements of quality place experience and interpretation, and (4) a sense of gratitude for those who served and of responsibility to maintain participatory traditions.

\section{Theme 1: The Triangle embodies the ideals of a nation and functions as a sacred place.}

The Lincoln Memorial and the plaza in front of the Lincoln Memorial are a nationally recognized gathering plaza for social movements as well as a round table for discussion regarding civic issues. The extraordinary history associated with the Lincoln Memorial, the Korean War Veterans Memorial, and the Vietnam Veterans Memorial motivates people to come. Indeed participants highlighted that the Triangle revealed concepts including some form of community attachment, symbolic meanings, and spiritual values. This place presents visitors with an array of historical events, actions, lives and places which stands witness to humans' highest values and greatest conflicts. Thus, a sense of holiness occurs without force. Some visitor experiences can be described as spiritual experiences in which visitors "relate to or [are] in touch with an 'other' that transcends one's individual sense of self and gives meanings to one's life at a deeper than intellectual level" (Schroeder, 1990). One participant likened these three memorials to a "cathedral of the soul:"

What these three monuments here mean to me is the spirit that pervades these grounds, [and this] is the spirit of sacrifice and humility, but at the same time, greatness; because the people who died [in these conflicts], left their mark here, and left their mark on this whole country. The dream is not quite finished, but it is still in the process of becoming a flower. All these three sites come together and they bring that [message]—without 
pain there is no gain. I do believe that places like this are the cathedral of the soul. They bring out the depth of all human beings and you begin to see what a nation is supposed to do to make all living things free (Man, Pre 4, p. 4).

Visitors recalled compelling historic events that have taken place at these sites and these memories evoke emotion. As one participant explained, "You cannot go to the capitol and not think of it—the things happening at the Lincoln Memorial-the civil rights movements. It is more than just a monument" (Post 7, p. 6). Another visitor recalled that Martin Luther King Jr. gave his famous speech "I Have a Dream" in front of the Lincoln Memorial and other protests of the Vietnam War occurred at this site. For him, the plaza is "a symbol of a great meeting place for people" (Post 7, p. 6).

Visitors also experienced emotions such as joy, sorrow, gratitude, and a sense of pride at the Triangle as they encountered an "other" that transcended themselves. To list a few:

- We have been here many times and you know what? I cry every time I come to the Vietnam Memorial. I can't help it (Man, Pre 5, p. 2).

- [These place teaches us things] so we can appreciate these men [who fought for us] and what they mean. These monuments are overwhelming for those who visit here for the first time (Woman, Post 7, p. 2).

- I don't know—when I look at Lincoln, I just feel warmth inside or something...It is very difficult to explain. It is something that makes your body kind of shake and say, "I am proud to be part of this country" (Woman, Pre 5, p. 1).

Visiting the Lincoln Memorial, the Korean War Veterans Memorial, and the Vietnam Veterans Memorial is a pilgrimage for some visitors; and they also seek extraordinary experiences. One woman expressed her true motivation to see the Lincoln Memorial by saying, "I don't care if I see anything else except the Lincoln Memorial. I've always had a special place in my heart for the struggle of the Civil War and what it all meant. It is very special to me" (Pre 11, p. 2). Another visitor described the image of the civil rights movement that flashed through his mind occurs before the "imposing 
statue" of Lincoln. He appreciated the opportunity to visit, to "take in the words" of Lincoln, and see the "father figure" that Lincoln represents (Man, Post 9, p. 4).

These places embody human ideals. These ideals are viewed as relevant to people's lives today. Visiting the site also solidifies a sense of the value of government and of country. Ideals including responsibility, sacrifice, democracy, the love of this nation, and the willingness of the American public to participate in conflicts that will ensure that Americans have freedom emerged in the focus group interviews. One participant related a sense of appreciation for those who fought and a sense of unfinished business:

I was thinking this triangle...I appreciate every man that fought in wars and it hurts me to see [the fact] that the Lincoln Memorial reminds us of a successful conflict that we came out of and that we've grown from. But then there is the Korean Monument where South and North Korea are still enemies [and] they're still fighting. Vietnam is still under Communism. And I think that these two [sites] remind us of the conflicts that we attempted to resolve and they still are unresolved. We still have battles to fight against our enemies (Woman, Pre 4, p. 6).

The following quotes illustrate the ideals of a nation:

- I think it is not easy to maintain your independence and your freedom. All [the memorials] reflect a lot of suffering and dying, and [so does] President Lincoln. So when you come here, it is special to see what these folks have done so that we can walk around and do what we want to do (Man, Post 7, p. 2).

- Woman 1: "We had some great men in this country, to be sure."

Woman 2: "But in order for Lincoln to be great, he had to have the ordinary guys or persons to do the job. Because without that..."

Woman 1: "I think what it really says to me is the willingness of the American public to participate in any conflict that will make sure that we have freedom" (Post 3, p. 4). 
- This is an opportunity for us to show the rest of the world what our ideals are supposed to be, and when we do something stupid, and when we show the wrong side of ourselves, maybe people coming here will say, "Somebody made a mistake, but this is what America really means. This is not about the gentleman sitting on that chair, it is about what these things tell us (Woman, Post 4, p. 5).

Study findings support that many visitors came to the site seeking emotional and/or spiritual experiences for themselves. In fact, some visitors were drawn to the site mainly because of the Lincoln Memorial. They show a strong desire to be inspired by the memorial: "For us, as native born Americans, the power of that memorial is the words that are there and the incredible statue of Lincoln in the center" (Man, Post 4, p. 3).

\section{Theme 2: Lincoln is a symbol of unity, strength, and freedom.}

The Lincoln Memorial evokes the ideal of freedom and represents the unification of the country. The statue of Lincoln constitutes the focal point and delivers one of the most significant themes to its visitors: "Lincoln kept the nation together" (Man, Pre 3, p. 5). Lincoln represents the preserver of the Union. Another visitor expressed his view that "Lincoln so solidly represents the Union, and also the idea that the country is one" (Man, Post 4, p. 9). Lincoln is held as a standard of what a person would do for his or her country, influencing the people who went through the struggle of wartime. The strengths of Lincoln's character include humility, endurance, leadership, and the ability to deal with personal suffering; these strengths challenge visitors to think about their responsibilities as a citizen. Two women discussed the "reminders" that Lincoln evoked in their daily lives:

Woman 1: "All these sayings are tremendous because we have forgotten them. That was a long time ago. Lincoln had tremendous [influence] and he lived by what he said."

Woman 2: "I always want to say, "How are we doing today?"” (Post 3, p. 9). 
Lincoln symbolizes the ideal and standard of what it means to be an American by his strength of character and by serving as a president, a freedom fighter, a professional (lawyer), a religious person (Christian), a citizen, and a father figure to guide the growth and improvement of the nation. Participants expressed their desire for a "Lincoln-kind of president" at present and in the future. One woman explained, "Abraham Lincoln is my favorite president. He is very inspirational, clearly a man who had a heart" (Woman, Post 6, p. 2). The site reiterates the value of charismatic leadership, which participants felt that America currently lacks, and the need to go back to those spiritual roots. One visitor indicates that "When you think of Lincoln, you realize that he was not just a president, but he was a spiritual man, too. Therefore, he saw in the decades and the centuries" (Man, Pre 4, p. 4). This visitor then stated the need for American people to return to the spiritual roots that Lincoln represents:

They [these historic characters] have a lot to teach us. The first thing that comes to my mind is that we have to regain our integrity. We need to go back to our spiritual roots and begin to understand that these things are here (Man, Pre 4, p. 5).

A large number of visitors showed their respect to Lincoln and their appreciation for what Lincoln has done for the nation. This participant's comments are typical in this regard:

We all want this ideal that we look up to, or what we see our nation ideally as. And it is easy to do it with someone that's a long-time dead, I suppose. [Lincoln] had good ideas and I think what he wanted as an outcome, and what he wanted for the nation was awesome. I think he was a great leader in that sense (Man, Post 9, p. 4).

International visitors also identified the significant role that Lincoln played in American history. A woman from England related the size of the Lincoln statue to the size of what Lincoln did for this nation:

I think that the size of the statue shows you the size of what he did.

Because we don't know all the ins and outs obviously—we have the 
English perspective. But, the size of the statue itself...tells the size of the things that he did for your country (Pre 11, p. 4).

Through an interpretive program, visitors could be inspired with compelling human stories and be provoked to care for park resources. One woman mentioned, "[Now] I have more understanding of [Lincoln] —it is good to get that feeling. You are supposed to be inspired by something powerful and by the ideals" (Post 4, p.12). One visitor recalled his on-site experience in this way:

[Lincoln] obviously was a very dynamic person. He went through very tough times in the nation's history. I just wanted to be there and read the Gettysburg Address and the Second Inaugural Address. You do get a special feeling, especially listening to the ranger's talk (Man, Post 8, p. 2).

Another visitor revealed a range of meanings that she ascribed to the Lincoln Memorial and that were stirred up by her on-site experience:

I think the Lincoln Memorial reminds me how important it is that we stay united as a nation. And how important it is that everyone is equal in our nation. I really admire Abraham Lincoln-his integrity and what he stood for, that he stood by what he believed in no matter what happened. I really admire him for that. That means a lot to me (Woman, Pre 4, p. 2).

Lincoln and the Lincoln Memorial also push visitors to recall the dark side of U.S. history that slavery represents. Two participants contemplated Lincoln's sense that the human toll exacted by the Civil War was, in essence, divine retribution for the sins of the land. By focusing on the idea of "penance," these participants began to ask penetrating questions about whether our penance has in fact been completed, and whether the price for our sins has been paid in full:

Man: "Another important point is that Lincoln believed deeply that the Civil War was about penance. We as Americans, both North and South, had committed a crime by buying into slavery. And we did not know when the war would end-there was a sentence there-maybe it will not end until every drop of blood is paid for with a drop of blood. That is very 
important. Americans tend not to want to think about the dark side. And what we have done is wrong. And that is something we can have with an historical perspective, [we can have] a new attitude. Lincoln is very contrasting, and maybe Americans can share that feeling, the sense that this is our penance, and that this war is going to go on until God has decided that we paid for it."

Woman: "Maybe we have not yet paid for it."

Man: "Exactly."

Woman: "So there should be a connection between now and the past. What he is saying is that what we [think we] accomplished, perhaps we didn't" (Post 4, pp. 10-11).

\section{Theme 3: Visitors have a strong sense of what constitutes a quality interpretive program and on-site experience at the Triangle.}

Participant comments revealed an awareness of the elements of quality place experience and how interpretation significantly contributed to that experience. Many of them expressed a desire for quality on-site interpretive experiences. Some participants who had attended an interpretive program articulated the importance of tangible experience and the use of tangible objects in interpretation. They demonstrated a strong desire to be provoked and find relevance among the resource. Almost all of the participants desired to be provoked by stories and gain a sense of connection with the past. Participants also show a desire to establish a personal bond with these places. And, they revealed the importance of opportunities for intellectual and emotional connections. In addition, visitors especially admired interpreters' love and passion toward site resources. They felt that interpreters' special relationship with the place had led visitors to better understand the insights of the historic and cultural elements of these places. 


\section{Tangible Experiences}

Study results show that many visitors want to have a quality place experience. Participant comments expressed a fervent desire to "experience" the Triangle. First of all, participants reflected on why physically "being here" contributed to such a powerful place experience. Physically being present in a significant place, moving through the site, viewing it from different angles, and immersing oneself in the richness of sensory experience can add to visitor enjoyment. One man suggested that on-site experience transforms head-knowledge into something physical, something personal, something that activates one's emotions:

That is why I wanted to come here, because I am fascinated with American history in particular. I can't imagine a better placed to come...I've read about it. I've learned about it. I've taken exams on it. But this actually makes it physical and makes it personal. I've seen pictures of it, but there's nothing like walking through the Smithsonian and seeing how black people were treated at the turn of the century and how the whole civil rights movement has evolved. That's very emotional (Man, Post 9, p. 9).

Secondly, many visitors fully enjoyed places where objects can be seen, touched, and felt-these objects enriched on-site experience and sometimes led to expanded appreciation. Tangible experience has the power to bring home the reality of the people, events and ideas being commemorated. A history teacher from Illinois said, "The first thing I thought about when we were walking down here is, I just remember seeing on TV the old black and white video [clip] of Martin Luther King. So it's very meaningful" (Woman, Pre 1, p. 7). Thirdly, some participants were able to recall their initial perspectives when they were first exposed to symbolic meanings of the Triangle, expanding on these initial perspectives by attaching new meanings to the resource. Other participants were less likely to make these mental transitions or connections. Many post program participants recalled how interpretation connected the tangible objects with their meanings and perspectives. And sometimes, that experience led to new meanings, values, and identities. One participant prized the chance to listen to a ranger who "made 
us think a little bit more huge, instead of just about the 'statue guy' up there" (Man, Post 1, p. 5).

\section{Universal Concepts and Symbols}

At the Triangle, tangible objects like the flag, the Vietnam Wall, the statue of Lincoln, and the statues of combat soldiers are catalysts that provoke visitors to think about universal concepts like "freedom" or "sacrifice" and thus enrich their on-site experience. As mentioned before, a universal concept, defined by the National Park Service, is any intangible meaning (e.g., idea, concept, system, process) that is relevant to almost everyone but that does not mean the same thing to any two people (NPS, 2000). Universal concepts can be any broadly relevant concept including family, love, death, justice and health. They can be applied to human relationships, cultural resources or the natural environment. Symbolic as those statues or landscapes may be, some people still cannot make the connection by just from cruising though the memorials. Because they had not attended an interpretive program before being interviewed, one group expressed with their frustration of not understanding the meanings associated with the etched granite wall at the Korean War Veteran Memorial:

Man 2: "I didn't realize until you [the moderator] said that those pictures are factual. That puts a different light on it."

Woman 1: "Yeah, because I would have taken much more time looking at it."

Woman 2: "When we came here, we didn't see the [faces of actual military and supply personnel and Korean citizens and the landscape that were etched on the wall]".

Man 1: "No, we didn't know that."

Woman 1: "That is why they need some indication somewhere" (Pre 5, p. 7).

It is useful to compare this pre-group's reaction with another group whose members had attended an interpreter-led program. These participants were thankful that they could better understand the resource: 
Man: "I didn't pay attention when I was there in front of the etching on the wall. So when the ranger took us through the sequence of the different services, the summer, the winter... When I first walked down and looked at it, I just saw people. I didn't really understand what the method was on that wall till the ranger explained it."

Woman: "When I first got over there... there wasn't anything. Had I not been lucky enough to be there [during the interpretive program], I probably would've walked away with a lot of questions in my mind" (Post 3, p. 8).

\section{Intellectual and Emotional Connections}

These participant comments demonstrate that interpretation at the Triangle enriched the on-site experience by facilitating the perspectives of the visitor and the symbolic meanings of the resource. This facilitation process allows visitors effortlessly draw upon their past perspectives and establish new personal meanings of the place. One participant highlighted her emotional connection with the Korean Memorial during the interpretive program that she had just attended: “... particularly when the ranger mentioned the [American] flag. [He said,] 'Whenever you see one of those, you know that is the one. It is for freedom.' I thought that was real personal' (Woman, Post 5, p. $4)$.

For those participants who had attended an interpretive program, many of them expressed that they had a quality place experience at the Triangle. Some participants also recognized the benefits of interpretation and understood that interpretive programs have the power to establish relevance and enhance intellectual and emotional connections with the meanings of the resource. These participants perceived that if interpretation is built around the cohesive development of an idea-especially an idea that also functions as a universal concept—it is extremely powerful. One participant observed: "I see these sites as having an overpowering message of freedom" (Man, Post 8, p. 3). One man viewed the phrase etched on the wall of the Korean War Veterans Memorial- "Freedom is not free"-as the central message of the memorial and a unifying concept linking the three 
sites at the Triangle. He commented, "That saying, ["Freedom is not free"], is the high tide of the memorial; it ties into the Lincoln Memorial and the Vietnam Memorial" (Post 8, p. 3). Participant comments also illustrated the power of universal concepts to provoke questions and facilitate reflection upon many levels of meaning:

Man: "This setting is being used for this one concept—-freedom. [As] Martin Luther King [Jr.] said in his great speech, 'Let freedom ring.' And there are a lot of people in the country who say are we free or aren't we free? But freedom comes at a great cost with the lives that were lost in the wars."

Woman: "And there are different levels of freedom. And that's what you have to be reminded of, too" (Pre 1, p. 7).

Emotional connections occurred when interpreters "fold" a universal concept such as "freedom" in the program to provoke visitors considering multiple aspects of the topic and reflecting upon the meanings in our lives today. Because the concept of freedom was viewed as relevant to their everyday life, participants reflected more deeply upon its meaning and considered ways to integrate emerging insights into their everyday lives. Study results suggest that many participants have a sense of the elements of quality interpretation. They identified that interpretation will be effective when it touches the human side of visitors and satisfies people's love of a good story: "Pure facts don't enthrall. Make it human. Tell a story based on fact, but elaborate if necessary" (Woman, Pre 2, p. 6). After attending a ranger-led program, a visitor was inspired and said:

I just thought that [ranger program] was an incredible presentation, probably one of the best I've ever heard. I really appreciate the way the ranger made the whole thing come alive. And I thought about it in terms of how unpopular Lincoln was in his day and yet he persevered and stuck with his ideas. The ranger talked about Lincoln's bad press and how he was maligned in the press on a daily basis, and yet he stuck with his ideals. I like that the ranger shared that with people-the struggle that Lincoln went through (Man, Post 1, p. 6). 
Another participant described how the use of the universal concept of "family" struck her during one interpretive program:

I think the ranger touched on that a little bit when he said that he saw that there were parents here with children and asked, "How would you feel if you lost a child?" He was pointing out that Lincoln lost more than one child. It is true of all these memorials. Like he said, this is somebody's brother, and somebody's son, and somebody's father... (Woman, Post 8, p. 7).

4. Cohesive Development of an Idea

In addition to incorporating triangle resources, using universal concepts, and helping visitors making their own connections, participants identified that a cohesive development of an idea or story also helped them experience quality interpretive and place experience at the Triangle. Elements that contributes to a quality interpretive program include:

- Be inspirational

- Be relevant

- Present a holistic picture

- Emphasize more the why than what

- Tell a story or present interesting trivia

- Link current civil, democratic, or management issues

- Be passionate about the resources
(Pre 4, p. 10; Pre 6, p. 9; Post 1, p. 5)

(Pre 1, p. 10; Pre 11, p. 7)

(Post 1, p. 3; Post 8, p. 4)

(Pre 2, p. 8; Pre 3, p. 3)

(Pre 11, p. 8; Post 6, p. 6; Post 7, p. 4)

(Pre 5, p. 7; Pre 6, p.7)

(Post 1, p. 7; Post 5, p. 3; Post 7, p. 5)

Not only did many visitors understand quality interpretation, many also wanted to have their experiences facilitated. Participants frequently recalled the details of ranger programs and discussed issues raised during the program with family members 
afterwards. Some visitors indicated their "relief" at having rangers help them solve puzzles and understand symbolic meanings inherent in the design of the memorial. Similarly, participants compared the differences before and after attending the ranger program-interpretative programs expanded their understanding of events, broadened their viewpoints, and enriched their visiting experience:

Because that saying ["Freedom is not free"] is the high tide of the memorial. That ties into the Lincoln Memorial and the Vietnam Memorial. [It is] something that gives you some understanding of what the memorial demonstrates. Because we walked through and we didn't understand what we were seeing. What the ranger described changed the whole picture for us. We were not educated too much about the Korean War. We saw that and I said, 'Yeah, I recognized it for what it is.' But I don't know what it means (Man, Post 5, p. 4).

One woman appreciated that the interpretative program stimulated her to explore a little deeper by saying: "I really like history, although when I come to a place like this, it really spurs me on to dig a little deeper. The presentation was very good. I think that really helps to bring alive the memorials..."(Woman, Post 8, p. 4). A British visitor recalled interpretation at the Alamo in Texas, emphasizing how story was used:

People remember those [stories]. I mean, you could reel off statistics and [things like] "this was built in 1846" and blah blah blah. But, "There was a little flower seller on the corner..."-[use] that made up story or whatever. Keep it human. That's definitely the way it goes. The example of the Alamo- - [the ranger] was giving us the names of people that were killed there. But you remember that. You remember the famous ones like Crockett and the others. Statistics, I think, we all get brochures and they give you either the date, the figures, the amount, how high, [and] how tall, but [it's those] human stories, you remember, I think (Woman, Pre 2, pp. $7-8)$. 
Several participants recognized the challenges of interpretation. One officer manager who held a history degree articulated the challenges of interpretation at the Triangle:

You just have about 15 minutes, so you really have to get to the main purpose of it. Generate some interest and get the ideas across of what this really means and put it in a way that people can understand easily (Man, Post 4, p. 10).

Most of all, interpreters' love, passion, and enthusiasm for park resources engaged visitors, fostered care and stewardship, and contributed to their visiting experience. A man expressed his appreciation for an interpretive program as follows:

The program was great. Because the ranger is a gentleman who had been [to the battlefield]. The ranger has the passion of the events, and of what occurred. It was still very close to the ranger. At our age, we have just heard about it, but we don't have an understanding about the topic and what just happened there. He was not just like other tour guides. He is a man with a passion. Because he can speak of it-you knew it was from the ranger's heart. It is good to listen to the ranger's talk (Woman, Post 5, pp. 3-4).

One cannot force another to love, neither can an interpreter force visitors to care about the resources if he or she doesn't care about the park in the first place. The following participants formed special bonds with the Lincoln and the Korean Memorial through the interpreters' love of those places and their commitment to their jobs:

- You do get a special feeling, especially listening to the ranger's talk. He is very good, very passionate (Man, Post 8, p. 2).

- I had passed through here quickly, because we didn't know anything about it — the soldiers, the division, the dividing line, [and] the clothing of summer and winter. [At first,] we passed through and thought, "That is pretty." And we came to the exit and you guys said join us. The ranger's passion captured us there. And that is from the heart (Woman, Post 5, p. 3). 
- Moderator: "So what are the differences between learning about things here compared to learning things in school classrooms?"

Child: "At least the ranger is not that boring."

Moderator: "Would you like to have the ranger as your teacher?"

Child: "Yeah, he'd be a pretty good teacher."

Man 1: "I have never seen a teacher that passionate about his subject matter."

Man 2: "He had his whole heart in it."

Man 1: "He really did" (Post 8, p. 6).

Theme 4: The Triangle inspires a sense of gratitude for the sacrifices of others and stimulates a desire to participate in democratic life.

The memorials create a sense of the strength of this country, the valor and patriotism of the U.S. leaders and common soldiers. The ideals that the Lincoln Memorial, the Vietnam Veterans Memorial, and the Korean War Veterans Memorial represent reveal the nation's goals and help to define Americans' identity. The sites remind visitors of the pain of wars and the struggle of the growing country. It also provides a window to the nation's past and encourages people to consider their complex heritage. The issues of war and peace and the yearning for freedom saturate the atmosphere. They also connect people to the present-inspiring and encouraging American citizens to participate in democratic life. One participant explained the impact that the Vietnam Veterans Memorial had upon him:

[During] the Vietnam [War], I was too young to really...I mean, I understood that things were going on, but I did not really understand the magnitude of that. And I didn't understand it until I saw the Wall. And then it was real. Then there were names there. There were people there scratching with their pencil on paper, and those were relatives or friends. 
And I saw how many people had been involved. And that was really moving to me (Man, Pre 6, p. 3).

Visitors appreciated those who served and commemorated their sacrifice. "Don't take it for granted" (Pre 11, p. 3) was a common admonition regarding freedom that we have today. Many participants expressed their realization of "how many people have done things that have given me the opportunity to be where I am and experience freedom" (Man, Pre 6, p. 4). Another participant wished her children would appreciate the kind of life that they have now:

I think it is important that any time people die for this country, that they be remembered. They paid the ultimate sacrifice. I think that our children wouldn't have been around during the Vietnam War, but I was. I think it is important to pass that along, to make sure that our children are aware of the sacrifices that were made. These sites teach us about the sacrifices, the people who gave themselves... (Woman, Post 8, pp. 2-3).

Visiting the memorials also provokes a sense of responsibility to uphold and achieve the national goals. In fact, the visiting experience functions as an "injection," so that people could still hold onto that special feeling even at their homes, giving them the strength and wisdom to participate in democratic life. One participant explained why it is so important for her to be inspired by these bigger ideals at the Triangle.

People are here for a common purpose. And I think when we leave here, we get that, like an injection of what we've long forgotten when we're back in our busy little city. We lose a sense of history. We don't really think about it. We don't really care about it. It just seems so amazing to me. Because when you're at home and you're in your individual lives, in the hubbub and the rush-rush of do this, do that, and the attitudes that people take, and the other things that exist - the crime and all that kind of stuff - it doesn't look like, or it doesn't appear, you don't get the sense that people even care about what's here or about being a community or caring or thinking or even wanting to entertain the idea of how did this all start. (Woman, Pre 1, pp. 6-7) 
Another participant recounted the most significant message that he received after attending an interpretive program at the Lincoln Memorial: "I think the most important thing is that these are memorials to the people that died to keep our country free, and safe for democracy. And more than anything else, that's what it's about-the people that paid with their lives for freedom [and] for democracy" (Man, Post 8, p. 7).

Participants stressed that not only can people work within the democratic system to avoid unnecessary conflict; but we are duty-bound to do so. Moreover, as citizens of a democracy the duty extends beyond decisions about war and peace. It extends to every decision people make about how we want to function as a society. "I think connecting with your past can help you plan for your future" said one participant. She continued to address the importance of having a connection with this nation's history and of our collective mission to "live as a nation:"

You can know what happened in the past and see what's going on in the present and figure out if you want the same thing in the future or not. And they represent a lot. They stand for a lot. They've done a lot of hard work - the people that we've honored. And remembering that, keeping it present helps us live as a nation, as a whole (Woman, Pre 1, p. 4).

Another man stressed the "higher responsibility" that all Americans share to uphold the ideals upon which this nation was founded:

We have a higher responsibility than other nations because we are the ones who said that 'All men are created equal.' And we are the ones who set ourselves up as the supporters of that ideal. Other countries did not do it. Nobody else ever made that promise or claim. And if we are going to make it—and we've made it for 220 years now—if we are going to make that claim, then we have the responsibility to at least attempt it. We are all human and no one is going to achieve that; but we have a high responsibility to attempt it (Man, Post 4, p. 6).

Participants recognized the importance of equality and social justice; they also perceived that there is strength in diversity. One man suggested that as we work together to overcome problems, a common bond of unity emerges: 
[This place teaches us that] however big the problem, and however diverse the people involved, if you all have a common goal you can get together and do it. All races, all religions, they have experienced what these [sites] memorialize. And we've all [overcome the problems] in the U.S. together (Woman, Post 1, pp. 4-5).

In summary, at first glance visitors relate to the Lincoln Memorial, the Korean War Veterans Memorial, and the Vietnam Memorial as interesting places to learn American history. However, a more in-depth analysis reveals that visitors are complex. They attach and ascribe diverse perspectives to the resources. In addition, participants seek to have in-depth experiences with the tangible site resources and cherish any opportunity to be inspired by meaningful conversation and quality interpretive programs. 


\section{Chapter Five}

\section{Discussion}

The results of the study indicate that visitors are deep, complicated, and their perspectives are worthy of on-going analysis. The study findings suggest several points that should be considered by front-line interpreters, interpretive trainers, interpretive managers and interpretive researchers. First, visitors actively ascribe meanings to site resources. Second, visitors are seeking a place experience that enables them to make a connection between the tangible resource and its intangible meanings. Third, many visitors want their experience to be facilitated. Fourth, interpreters should consider how an understanding of visitor meanings could improve interpretive work. Management implications and study limitation were also discussed in this chapter.

\section{$\underline{\text { Visitors Actively Ascribe Meanings to Site Resources }}$}

Visitors are concerned about food, lodging, restrooms, and taking pictures. However, these basic needs are not the only few things that visitors do and care about at significant heritage sites such as the Lincoln Memorial, the Korean War Veterans Memorial, and Vietnam Veterans Memorial. The researchers observed that visitors of all ages, genders, regions, number of visits, nationalities, ethnic backgrounds, had or had not attend an interpretive program actively ascribe various categories of meanings. They think about resource meanings, discuss those meanings, and create new understandings and meanings for themselves and others. They bring multiple perspectives to the site. Study results demonstrate that visitors engage the meanings inherent in the sites at the Triangle; they also ascribe more personalized meanings that reflect their own experiences and understandings. Visitors may or may not be capable of utilizing language to articulate their ways of thinking or personal experiences. Many, perhaps most, visitors ascribe and connect with meanings they can only vaguely articulate or unravel. For example, one participant found herself at a loss to adequately explain her experience: "I don't know, when I look at Lincoln, I just feel warm inside or something. It is very difficult to explain. It is something that makes your body kind of shake and say 'I am proud to be part of this country"" (Woman, Pre 5, p. 1). Although hard to articulate, 
participants did express a wide range of meanings including freedom, sacrifice, patriotism, gratitude, unity, perseverance, penance, equality, democracy, heroism, and responsibility. One of the most significant study results is to confirm that visitors $d o$ ascribe meanings to the three memorials at the triangle and they see these meanings as relevant to their personal lives.

Littlejohn and Hoffman (1999) found that the majority of the NCP - Central visitors (64\%) came to learn about U.S. history. This study documents that visitors ascribe meanings which encompass far more than simply learning about history. Visitors seek a sense of connection with the past which in turn leads them to ponder present issues.

Resources have meanings and are relevant to adults. Many Triangle visitors recalled the protests and speeches in front of the Lincoln Memorial and the Reflection Pool during the civil rights movement era. Because of the famous events that occurred there, the sites helped visitors transcend the time barrier and led them back to the $1960 \mathrm{~s}$, to the moment when they saw a historic news program or film clip on television. One woman mentioned that "the first thing I thought about when we were walking down here is, I just remember seeing on TV the old black and white video of Martin Luther King, so it's very meaningful" (Woman, Pre 1, p. 7).

Resources have meanings and are relevant to children as well. School children discussed subjects they had learned in school, emphasizing that seeing the monuments and memorials made these historic people and events "real and alive." As one child mentioned, "it is a lot more meaningful to see all the names [on the Vietnam Wall.] You see them in the textbook, but you do not really realize all the lives that were lost in the Vietnam War (Child, Pre 4, p. 8). Another mother who was also a teacher said, "It has meaning for us. I think it is important that children see where they've come from, and from that they get their respect for what has happened before to put them where they are now" (Woman, Pre 11, p. 3).

Study participants have a mix of deep and complex perspectives as well as much not so deep and complex perspectives. The simple question of "What drew you to this site today?" revealed diverse visitor meanings of place. These meanings and values include a personal affection and respect for President Lincoln; the commemoration of a 
loved one who served in the wars; the desire to visit a famous tourist destination; or simply an interest in participating in a social event (i.e. local residents hosting out-oftown guests or individuals accompanying their loved ones). While some visitors do bring serious and complex perspectives, some reveal to much less deep or elaborate perspectives. Whether deep or not, visitors do not represent blank sheets. Their previous experiences influence the meanings they bring with them and the meanings they form on site.

Study results suggest that participants described the Triangle as a center of meanings formed through their past and on-site place experiences. This given geographic locale became a meaningful place when visitors attached personal or group meanings to it. For example, one may attach a range of personal meanings to the Korean Memorial, such as the American flag represents freedom and a sense of patriotism. A group of people (i.e. family or veteran organization) may also relate to the Lincoln Memorial or the Vietnam Memorial as symbols of their beliefs and values. Through attaching personal or group meanings to place, people acquire a sense of belonging and purpose that can give meanings to their lives (see Theme1: The Triangle as a sacred place). Study results suggest that that participants ascribe symbolic, emotional, cultural, and political meanings to the Triangle.

Do the pre and post group participants have the same ability ascribing meanings of the Triangle? Hand-coding content analysis results suggest that the post program participants were more likely to use the exact "place names" and "historic character names" when explaining what drew them to the site. These post group participants were more likely to recall their on-site experience, refer back to the key points of the ranger program that they had just attended, connect tangible resource with symbolic meanings, and form personal meanings to the site resources. One explanation of the difference is that interpretation helps the processes of shadowing and selective attention (Ham, 1992, pp. 12-15). Familiarity allows the human brain to expend less effort to concentrate on personal and meaningful content (Moray, 1959; Cherry, 1966). And the use of universal concepts helps people effortlessly switching their attention to things they care about even when they are not consciously trying to (Solso, 1979). 
Visitors Seek An On-site Experience that Enables Them to Make A Connection between the Tangible Resource \& Its Intangible Meanings

Washington, DC is obviously a familiar place in the minds of American people. It is the national capitol, the center of political power, and the background of every television news programs. Every student studies the story of President Lincoln, the history of the Civil War, and the struggle of civil right movements. The image of the Lincoln Memorial is on the back of every penny. People who have never visited the Vietnam Memorial know it by name and value it. They also may have an image of the place based on the movies they had seen or the stories they had heard. Galliano \& Loeffler (1999) highlighted the experiences that media could not deliver at a place:

The human experience can sometimes exceed the expectations created by the media. Thus, the interpretation of a place through direct, personal experience exposes identities, meanings, and images that may not have been expected (p. 3).

One participant comment echoed this point: "In high school, you learned about legislative process, but you didn't realize the power of the government until you came here. I thank for every American, they should come here at least once" (Man, Post 4, p. 12)

Study results also suggest that visitors come to the Triangle seeking an experience. Visitors do not primarily seek knowledge or learning-although interpreters and educators sometimes view learning as visitors' primary motivation (More, 1983; Loomis, 1996). If learning were their main objective, visitors could obtain almost all relevant information off-site. Instead, many visitors seek intellectual and emotional connections with the meanings of the resource. They seek an opportunity to interact with significant places. In addition, visitors desire to form a range of attachments, relevance, relationships, affiliations, or connections with places through experiencing a variety of feelings: care, concern, sentiment, warmth, love, and even sacredness. On-site experience allows visitors to link the biophysical landscape and tangible symbols to preexistent and newly emerging meanings. In many cases, this process is one of personalizing resource meanings and making them their own. For example, even a 
"Kodak Moment" may be highly meaningful to some visitors as one participant explained:

The statue of Abraham Lincoln-I always wanted my picture to be, to have a picture close with the great man who had made the important, I will say, history of making this country. I think he was one of the first and the most important ones (Man, Post 1, p. 2).

Visitors value an on-site personal or group experience that enables them to make a connection between the tangible resource and its intangible meanings. Many return visitors explained why they brought their children to the Triangle, - that is to have them experience a wonderful place to have history come alive" which they first experienced when they came with their parents. Others wanted to provide their children with an opportunity to visit an "overwhelming" place in American history. Significant heritage places have not only geographic or architectural bases, but also a history that joins the past, present and future. In addition, there is a wide range of adjunct of activities and events related to the Triangle. Each of these aspects of place is significant to visitors.

It seems like that the post group participants had a stronger tendency to transform and store long-term visual memories than the pre group participants. This woman highlighted how her past and present experiences formed new personal and generational meanings:

"I remember being a little girl with my parents. And every time I read anything about him [President Lincoln] or learned anything about him, I pictured the memorial, the statue. Then I brought my children back and I felt a little more in charge. Because I am this tall, much taller. And now I feel more in charge. And for myself I have more understanding of it. It's good to get that feeling. You are supposed to be inspired by something powerful and by the ideas" (Woman, Post 4, p. 12) 


\section{Many Visitors Want Their Experience to be Facilitated}

I live here and I have done the park sites around here and in Virginia. I like to listen to as many talks as possible. I can't remember that I was ever disappointed. They have different styles. They tell different stories. But I have never recall leaving a site and being disappointed. I always think I walk away with something (Man, Pre 7, p. 5).

Study results reveal that many visitors want their experience facilitated. They appreciate interpretive services that help them make intellectual and emotional connections to the meanings of the resource. Many visitors desire quality interpretive services to enrich their on-site experiences. One participant stressed: "The Park Service does a tremendous job in helping to add perspective to that. Like the self-guided tour. And the ranger's talk about the Lincoln Memorial and Lincoln [helped] add a lot of perspective. It is a great experience." (Man, Post 6, p. 4).

Interpreters' knowledge of the resources, authenticity of experiences, and love of their jobs help visitors connect with the meanings of the resources. Interpreters who lack direct experience with the event, time period, or person being commemorated can still facilitate a meaningful on-site experience:

I just thought that the [ranger program] was an incredible presentation, probably one of the best I've ever heard. I really appreciate the way the ranger made the whole thing come alive. And I thought about it in terms of how unpopular Lincoln was in his day and yet he persevered and stuck with his ideals. The ranger talked about how Lincoln was maligned in the press on a daily basis, and yet he stuck with his ideals. I like that the ranger shared that with people - the struggle that Lincoln went through (Man, Post 1, p. 6).

Indeed many visitors have asked themselves: "What makes this place significant?" or "what do these resources mean for my life?." If they have already ascribed a wide range of meanings to the resource, they are less likely to require interpretation. However, they may still appreciate an opportunity to gain additional meanings, to share a ranger's passion for the resource, or to participate in a shared 
experience with those who also value what the site represents. Many visitors are aware that the resource has meaning - they know there is something powerful there-but they lack the knowledge or personal experience to connect to those meanings or interpret what they're seeing. One couple described how attending an interpretive program at the Korean War Veterans Memorial totally changed the nature of their on-site experience:

Man: "Freedom is not free" is a very powerful emphasis, just like democracy. For those people who miss the corner (where the message is etched) will miss the message. I think there should be a sign right there saying "Freedom is not free", right at the central point. Because that is the high tide of the memorial. That ties into the Lincoln Memorial and the Vietnam Memorial. [It is] something that gives you some understanding of what the memorial demonstrates also. Because we walked through and we didn't understand what we were seeing. What he described changed the whole picture for us. We were not educated too much about the Korean War. We saw that and I said, "Yeah, I recognized it for what it is. But I don't know what it means (Man, Post 5, p. 4).

Woman: We were the lucky ones. How many people walk through it but do not know what they are seeing? (Post 5, p. 5).

Many visitors seek an interpretive experience. "These monuments are overwhelming for those who visit here for the first time" (Woman, Post 7, p. 2). A hallmark of quality on-site experiences is that visitors form intellectual and emotional connections with the meanings of the resource. Interpretation facilitates these connections, and many visitors indicated this is exactly what they want. One participant revealed this interest in a quality interpretive experience by urging interpreters: "Pure facts don't enthrall. Make it human. Tell a story based on fact, but elaborate if necessary" (Woman, Pre 2, p. 6). 
Interpreters Should Consider How An Understanding of Visitor Meanings Could Improve Interpretive Work

Freeman Tilden once urged interpreters to recognize visitors" "pre- condition" in terms of understanding park resources and work with that: "The visitors who come for his services have seldom any expert, or even moderate, knowledge of the things they come to see or to experience. They come frequently with mere idle curiosity, or to kill time, or from boredom" (Tilden, 1977, p. 91). Visitors may not have an expert knowledge of the resources, however, visitors do ascribe a wide range of meanings to the Lincoln Memorial, the Vietnam Veterans Memorial, and the Korean War Veterans Memorial. The question remains, however, can interpreters identify what these meanings are? And, if they can, how should they respond? How should an understanding of visitor meanings influence interpretive work?

If interpreters understand visitor meanings, they should be less inclined to underestimate visitors, and this in turn should facilitate respectful dialogue. In addition, visitors tend to rally around certain meanings as highly significant and highly relevant. Incorporating these meanings into on-site interpretation increases the likelihood of establishing relevance and facilitating intellectual and emotional connections.

Interpreters are not limited to incorporating generalized visitor meanings; for example, an effective interpretive technique might be to include actual visitor quotes in interpretive programs. Since visitor meanings are not a static phenomenon, interpreters should strive to continually expand their understanding of visitor meanings. The simplest way for an interpreter to expand or update their knowledge of visitor meanings is to conduct informal visitor interviews. Asking a few simple questions like those used in these focus group interviews (i.e., What drew you to the site today? What do these sites teach us?) should enable interpreters to better understand visitor meanings. In addition, the simple act of talking to visitors and eliciting their perspectives should help renew an interpreter's passion for the resource and for the visitors themselves.

Because visitors seek an experience, interpretation is best measured not by the information imparted, but rather by the meanings that are connected to. Meanings are more important than information; though they are supported by information. Meanings facilitate active engagement and provide an opportunity for intellectual and emotional 
connections. The tangible resource focuses meanings and has the potential to reveal multiple perspectives on the meanings of the resource. For visitors to make meaningful connections, their on-site experience must relate to something personal within themselves (Tilden, 1977). Each visitor will connect with different tangible resources and with different meanings depending upon their background, their life experiences, and the meanings they bring with them to the site. To facilitate meaningful on-site experiences, interpreters should consider two approaches to linking tangible resources to intangible meanings. First, interpreters should ask themselves, "How can the whole site be linked to its transcendent meanings?" Participant comments testify to the power of this approach:

This setting is being used for one concept—freedom. [As] Martin Luther King [Jr.] said in his great speech, 'Let freedom ring.' And there are a lot of people in the country who say are we free or aren't we free? But freedom comes at a great cost with the lives that were lost in the wars (Man, Pre 1, p. 7).

Second, interpreters must consider, "How can 'the parts' be used to focus attention on meanings?" The following exchange illustrates the effectiveness of this approach:

Man: "That was great, because [the ranger] is a gentleman who had been there. He has a passion for the events, for what occurred."

Woman: "Particularly when he mentioned the flag. [He said,] whenever you see one of those, you know, that is the one. It is for freedom. I thought that was real personal" (Post 5, p. 4).

In analyzing research results, the researchers were continually reminded not to underestimate visitors. Park interpreters frequently answer questions like "Where is the restroom?" or "When is the next tourmobile scheduled to arrive?" It is understandable that rangers are overwhelmed by the bombardment of the "ludicrous questions" that visitors ask and then assume that visitors want pure information regarding the memorials and need a basic orientation to the site. However, these frequently asked questions do not begin to reflect to deeply held and even profound meanings that visitors often attach to 
park resources. Visitors usually started a conversation with a ranger by asking a "lead-in question" though their intent may be to know more about the meanings and the humanity behind the memorials. When a visitor asks, "When was the Lincoln Memorial built?", that person may also want to think about "Why do we have the Lincoln Memorial at all?"

\section{$\underline{\text { Management and Training Implications }}$}

This study recognizes that visitors are deep, complex, and worthy of in-depth understanding and analysis. Study findings then urge interpretive management and training professionals to incorporate visitor meanings of place into interpretive planning and programming. Interpreters could use the following process to elicit and incorporate visitor meanings of place:

1. Invite a group of visitors to a roundtable discussion and encourage them to share their perspectives regarding to the meanings of the resources.

2. Use friendly questions such as "Where are you from?," "What drew you to this place?" or "What does this place teach us?" to start the conversation.

3. Record key issues during the conversation.

4. Conduct appropriate number of interviews according to site characteristics.

5. Identify the multiple perspectives and categories of meanings that visitors attached to site resources.

6. Encourage interpreters to develop programs using key visitor meaning categories. Include "visitor quotes" in programs.

To summarize, visitors do attach meanings to sites, seek personal experiences, value interpretive services, and care for park resources. They have a strong sense of what constitutes a quality interpretive program. When a interpreter facilitates a connection between the meanings of the resources and the interests and perspectives of the visitors, the visitors then connect to a "universal concept." When this occurs, then, visiting a significant heritage site is more than "seeing" and "learning," but transforms into a meaningful personal experience. The importance of this process is highlighted by one participant's response to the question "If you were an interpreter, what would you tell your audience?": 
I will try to almost grab them by the sense that this is something important. This is important stuff. I know people do not want to hear that. People are on vacation, it is not supposed to be school, and it is not supposed to be educational, but it is. It is important. And the Lincoln Memorial is my favorite, more so than the others. Jefferson comes close. And the two walls. Lincoln's second Inaugural Address is right there. It is important. Read this. This is what it is. And it does not matter whether stock went up 20 points today on Wall Street. In the big scheme of things, this is it. This is what it is all about (Man, Post 4, p. 10). 


\section{Chapter Six}

\section{Conclusion}

In the past two decades, resource managers and interpretive researchers have focused their efforts more on the management end: how to deliver agency messages; how to make the programs more effective; how to attract visitors to learn new information in a leisure setting; or how to educate visitors so that they would conserve resources or reduce vandalism. This study (1) emphasizes the importance of recognizing the range of visitors' meanings of heritage resources and (2) confirms that visitors ascribe meanings, seek on-site experiences, and (3) suggests that many visitors want their experiences to be facilitated.

Study results reveal that visitors desire an expanded understanding of the meanings of site resources, a sense of connecting with significant places, and in some cases, a spiritual experience. They articulated a range of pre-existing meanings that they ascribe to resources at the Triangle. They related how on-site experience amplifies and expands these meanings. And they provided insight into how interpreters can facilitate a quality on-site interpretive experience. Visitor comments underscore the importance of not underestimating visitors. Visitors think about the meanings of the resources in ways that reflect keen insight, high ideals and aspirations, a deep and abiding gratitude for those who served, a commitment to democracy, and an understanding of how interpretation works. Identifying visitor meanings and incorporating them into interpretive programs is one way in which interpreters can initiate a respectful dialogue with visitors. The potential pay-off of this two-way dialogue is that interpreters may help visitors relate to sites in a way that transcends their sense of self, provides meaning at a deeper than intellectual level (Schroeder, 1990), and provokes a sense of care and stewardship. Devising ways to improve interpretive training by linking it to visitor meanings research remains an important, but unmet goal of this study. In sum, this study identified a wide range of meanings visitors attach to three significant places on our national landscape. It also explored the role an expanded understanding of visitor meanings can have in improving interpretation. Understanding visitor meanings, and 
integrating that understanding into interpretive program development, represents an exciting challenge for the interpretive profession. 


\section{Summary}

This study explored a holistic approach to interpretive research that is based on understanding the meanings visitors attach to park resources. Study findings address three key issues (1) identifying of the meanings visitors ascribe, (2) exploring the types of on-site interpretive experience, and (3) considering how best to facilitate visitor on-site experience. Four themes emerged from the focus group interview data about the meanings of the Triangle at $\mathrm{NCP}-\mathrm{Central}$. The study data suggest that post program participants were more likely to use the exact "place names" and "historic character names" when explaining what drew them to the site. These post group participants were more likely to recall their on-site experience, refer back to the key points of the ranger program that they had just attended, connect tangible resource with symbolic meanings, and form personal meanings to the site resources. Management and training implications were addressed to enrich interpreting and visiting experiences. Finally, understanding visitor meanings should contribute to the provision of quality place experiences and interpretive services, stimulate an ethic of resource stewardship, and foster a commitment to participatory lifestyle. 


\section{References}

Appleyard, D. (1979). The environment as a social symbol: Within a theory of environmental action and perception. American Planning Association Journal, 53, 143153.

Babbie, E. (1995). The practice of social research. ( $7^{\text {th }}$ Ed.). CA, Belmont: Wadsworth Publishing.

Ballinger, N. L., \& Manning, R. E. (1997). Sense of place: Mount Desert Island residents and Acadia National Park. In H. G. Vogelsong (Ed.). Proceedings of the 1997 Northeastern Recreation Research Symposium (pp. 85-88) (General Technical Report No. NE-241). Radnor, PA: USDA Forest Service, Northeastern Forest Experimental Station.

Beeson, J. E., Stewart, W. P., \& Stokowski, P. A. (1996). Environmental settings and social interaction: The construction of place identity. In the Sixth International Symposium on Society and Resource Management: Social Behavior, Natural Resources, and the Environment (p. 191). University Park, PA: The Pennsylvania State University.

Bengston, D. N., \& Xu, Z. (1995). Changing National Forest values: A content analysis. (Research Paper No. NC-323). St. Paul, MN: USDA Forest Service, North Central Forest Experiment Station.

Bennett, J. R. (1998). From patriotism to peace: The Humanization of war memories. The Humanist, 58(5), 5-9.

Bitgood, S. (1994). A primer on memory for visitor studies professionals. Visitor Behavior, 6(2), 4-7.

Brandenburg, A. M., \& Carroll, M. S. (1995). Your place or mine?: The effect of place creation on environmental values and landscape meanings. Society and Natural Resources, 8, 381-398.

Bricker, K., \& Kerstetter, D. (1997). Special places: A exploratory analysis of sense of place for whitewater recreationists on the South Fork of the American River. Unpublished manuscript, The Pennsylvania State University.

Brockman, C. F. (1978). Park naturalists and the evolution of National Park Service interpretation through World War II. Journal of Forest History, 22(1), 24-43.

Buttimer, A. (1980). Home, reach, and the sense of place. In A. Buttimer \& D. Seamon (Eds.). The human experience of space and place (pp. 166-187). London: Croom Helm. 
Cable, T. T., Knudson, D., Udd, E., \& Stewart, D. (1987). Attitude changes as a result of exposure to interpretative messages. Journal of Park and Recreation Administration, 5(1), 47-60.

Cherem, G. J. (1977). The professional interpreter: Agent for an awakening giant. Journal of Interpretation, 2(1), 3-16.

Cherry, C. (1966). On human communication. (2nd ed.). Cambridge, MA: Massachusetts Institute of Technology.

Coolsey, R. W., Dickson, T. L., \& Loomis, R. J. (1982). Preferences for recreational environmental: Theoretical considerations and a comparison of models. Leisure Sciences, 9, 201-212.

Crawford, P. (1998). Environmental values and individual votes. In the Seventh International Symposium on Society and Resource Management: Culture, Environment, and Society (p. 176). Columbia, Missouri: University of Missouri-Columbia.

Fischer, D. H. (1999). A sense of place. Humanities, 20(4), 4-13.

Fishwick, L., \& Vining, J. (1992). Toward a phenomenology of recreation place. Journal of Environmental Psychology, 12, 57-63.

Fly, L. M., \& Tarrant, M. (1996). Elements of community attachment in southern Appalachia. In the Sixth International Symposium on Society and Resource Management: Social Behavior, Natural Resources, and the Environment (p. 191). University Park, PA: The Pennsylvania State University.

Forest Service. (1990). Objectives and policies of the interpretive services program (Publication No. FSM. 2390. 2). Washington, DC: USDA, Forest Service.

Freye, K. B., \& Virden, R. J. (1998). A conservation with Navajo about the meaning of place attachment. In the Seventh International Symposium on Society and Resource Management: Culture, Environment, and Society (p. 177). Columbia, Missouri: University of Missouri-Columbia.

Galliano, S. J., \& Loeffler, G. M. (1999). Place assessment: How people define ecosystems. (General Technical Report. No. PNW-GTR-462.) Portland, OR: USDA Forest Service, Pacific Northwest Research Station.

Griest, D. L., \& Mullins, G. W. (1984). Managing conflict: A process for increasing use of interpretation as a management tool. Journal of Interpretation, 9 (1), 1931.

Grumbine, R. E. (1994). What is ecosystem management? Conservation Biology, 8(1), 27-38. 
Ham, S. H. (1992). Environmental interpretation: A practical guide for people with big ideas and small budgets. Golden, CO: North American Press.

Ham, S. H., \& Krump, E. E. (1996). Identifying audience and messages for nonformal environmental education-A theoretical framework for interpreters. Journal of Interpretation Research, 1(1), 11-23.

Hammitt, W. E. (1982). Attention, familiarity, and effective interpretation. Journal of Interpretation, 7(2), 1-9.

Hammond, J. L. (1985). Wilderness and heritage values. Environmental Ethics, $\underline{7}(2), 165-170$.

Hayward, D. G., \& Larkin, J. W. (1983). Evaluation visitor experiences and exhibit effectiveness at Old Sturbridge Village. The Museum Studies Journal, 1(2), 4251 .

Henderson, K. A., \& King, K. (1999). Youth spaces and places: Case studies of two teen clubs. Journal of Park and Recreation administration, 17(1), 28-41.

Henerson, M. E., Morris, L. L., \& Fitz-Gibbon, C. T. (1978). How to measure attitudes. Beverly Hills, CA: Sage Publications.

Hester, R. (1985). Subconscious landscape of the heart. Place, 2(3), 10-22.

Hilten, J. \& Hilten, R. (1997). A sense of place for environmental education and interpretation. Legacy, 8(2), 10-13, 36.

Hungerford, H. R., \& Volk, T. L. (1990). Changing learner behavior through environmental education. Journal of Environmental Education, 21(3), 8-21.

Jacob, G. R., \& Schreyer, R. (1980). Conflict in outdoor recreation: A theoretical perspective. Journal of Leisure Research, 12, 368-280.

Jones, C. (1996). Evaluating the construct validity of sense of belonging as a measure of landscape perception. In the Sixth International Symposium on Society and Resource Management: Social Behavior, Natural Resources, and the Environment (p. 192). University Park, PA: The Pennsylvania State University.

Krueger, R. A. (1994). Focus group: A practical guide for applied research. (2nd ed.). Thousand Oaks, CA: Sage Publications.

Kubel, P. F., \& Leone, R. A. (1997). History is more than dates: A practical approach to heritage interpretation. Legacy, 8(1), 16-17,36.

Larsen, D. L. (n.d.). What's the meaning of this?: Resource management and interpretive advocacy. Unpublished manuscript. 
Larsen, D. L. (1997). Module 101: What interpretation is. Interpretive Development Program Homepage. [On-line]. Available: http://www.nps.gov/idp/interp/101/lesplan.htm

Larsen, D. L. (1998). Observation for "Quest" meeting. Unpublished manuscript.

Littlejohn, M., \& Hoffman, C. (1999). National monuments and memorialsWashington, DC: Visitor study. (Visitor Services Project Report 105). Washington, DC: National Park Service.

Loomis, R. J. (1996). How do we know what the visitor know?: Learning from interpretation. Journal of Interpretation Research, 1(1), 39-45.

Lustig, L. W. (1982). The use of interpretation to reduce vandalism and maintenance costs: An Interpreter's in-field formula. Journal of Interpretation, 7(2), 1929.

Lynch, K. (1960). The image of the city. Cambridge, MA: Massachusetts Institute of Technology Press.

Machlis, G. E. (1992). Interpreting war and peace. In G. E. Machlis, \& D. R. Field (Eds.), On interpretation: Sociology for interpreters of natural and cultural history (Revised ed., pp. 233-244). Corvallis, OR: Oregon State University Press.

Mahaffey, B. D. (1970). Effectiveness and preference for selected interpretative media. Journal of Environmental Education, 1(4), 125-128.

Martinez, D. A. (1988). Interpreting controversial historic sites: Insights and strategies applied at Custer Battlefield and the USS Arizona Memorial. Program Paper of the National Interpreters Workshop (pp. 144-154). Fort Collins, Association of Interpretive Naturalists.

Masberg, B. A. (1996). Using ecotourists to assist in determining the content for interpretation. Journal of Park and Recreation Administration, 14(2), 37-52.

Masberg, B. A., \& Silverman, L. H. (1996). Visitor experiences at heritage sites: A phenomenological approach. Journal of Travel Research, 34, 20-25.

McCool, S. F., \& Martin, S. (1994). Community attachment and attitudes toward tourism development. Journal of Travel Research, 32(3), 28-34.

McCool, S. F., Stankey, G. H., \& Clark, R. N. (1985). Choosing recreation settings: Processes, findings, and research directions. In G. Stankey \& S. McCool (Compliers), Proceedings-Symposium on Recreation Choice Behavior (General Technical Report No. INT-184) (pp.1-8). Ogden, UT: USDA, Forest Service Intermountain Research Station. 
Meredith, J. E., \& Mullins, G. W. (1995). Interpretation and the affective learning domain. Legacy, 6, 24-31.

Miles, M. B., \& Huberman, A. M. (1994). Qualitative data analysis. (2nd ed.). Thousand Oaks, CA: Sage Publications.

Milton, B., Cleveland, E. \& Bennett-Gates, D. (1995). Changing perceptions of nature, self, and others: A report on a park/school program. Journal of Environmental Education, 26(3), 32-39.

Mitchell, J. R., Force, J. E., Carroll, M. S., \& McLaughlin, W. J. (1993). Forest places of the heart: Incorporating special spaces into public management. Journal of Forestry,91(4), 32-27.

Moore, R. L., \& Graefe, A. R. (1994). Attachments to recreation settings: The case of rail-trail users. Leisure Sciences, 15, 17-31.

Moray, N. (1959). Attention in dichotic listening: Effective cues and the influence on instructions. Quarterly Journal of Experimental Psychology, 11(1), 56-60.

More, T. A. (1983). The nonusers of an urban forest interpretative center. Journal of Interpretation, 8(1), 1-9.

Mullins, G. W. (1984). The changing role of the interpreter. Journal of Environmental Education, 15(4), 1-5.

National Park Service. (1997). Module 101: Why we do interpretation: Meeting the NPS mission. Interpretive Development Program Homepage. [On-line]. Available: http://www.nps.gov/idp/interp/101/index.htm

National Park Service. (1998a). Korean War Veterans Memorial Homepage [Online]. Available: http://www.nps.gov/kwvm/

National Park Service. (1998b). Lincoln Memorial Homepage [On-line]. Available: http://www.nps.gov/linc/

National Park Service. (1998c). Vietnam Veterans Memorial Homepage [Online]. Available: http://www.nps.gov/vive/

National Park Service. (1999). All about the program. Interpretive Development Program Homepage [On-line]. Available: http://www.nps.gov/idp/interp/

National Park Service. (2000). Module 101: How interpretation works: The interpretive equation. Interpretive Development Program Homepage. [On-line]. Available: http://www.nps.gov/idp/interp/101/howitworks.htm

Niebuhr, G. (1994, November, 11). More than a monument: The spiritual dimension of these hallowed walls. New York Times, p. A12. 
Palmer, L. (1987). Shrapnel in the heart: Letters and remembrances from the Vietnam Veterans Memorial. New York: Random House.

Patton, M. Q. (1987). How to use qualitative methods in evaluation. Newbury Park, CA: Sage Publications.

Proshansky, H. M. (1978). The city and self-identity. Environment and Behavior, 10, 147-169.

Proshansky, H. M., Fabian, A. K., \& Kaminoff, R. (1983). Place-identity: Physical world socialization of the self. Journal of Environmental Psychology, 3, 57-83.

Rakow, S. J., \& Lehtonen, L. (1988). Environmental center educational programs: A national survey. Journal of Interpretation, 12(2), R1-R4.

Relph, E. (1976). Place and placeness. London: Pion.

Reyburn, J. H., \& Knudson, D. M. (1980). Program factors influencing attendance naturalists' programs. Journal of Interpretation, 5(1), 13-15.

Roggenbuck, J. W., Williams, D. R., \& Bobinski, C. T. (1992). Public-private partnership to increase commercial tour guides' effectiveness as nature interpreters. Journal of Park and Recreation Administration, 10(2), 41-50.

Ryden, K. C. (1993). Mapping the invisible landscape: Folklore, writing, and the sense of place. Iowa City, IA: University of Iowa Press.

Schreyer, R., \& Roggenbuck, J. W. (1981). Visitor images of national parks: The influence of social definitions of place on perceptions and behavior. In D. Lime, \& D. Field (Eds.). Some recent products of river recreation research (pp. 39-44) (General Technical Report No. NC-63). USDA Forest Service, North Central Forest Experimental Station.

Schroeder, H. (1990). The spiritual aspect of nature: A perspective from depth psychology. In G. Vander Stoep (Ed.), Proceedings of the 1991 Northeastern Recreation Research Symposium (pp. 25-30) (General Technical Report No. NE-145). Radnor, PA: USDA Forest Service, Northeastern Forest Experiment Station.

Schroeder, H. (1991). Preference and meaning of arboretum landscape: Combining quantitative and qualitative data. Journal of Environmental Psychology, 11, 231-248.

Schroeder, H. (1996). Voices from Michigan's Black River: Obtaining information on "special places" for natural resource planning. (General Technical Report ) St. Paul: USDA, Forest Service, North Central Forest Experimental Station.

Selin, S. W., \& Howard, D. R. (1988). Ego involvement and leisure behavior: A conceptual specification. Journal of Leisure Research, 20(3), 237-244. 
Simonson, H. P. (1989). Beyond the frontier: Writers, western regionalism, and a sense of place. For Worth, TX: Texas Christian University Press.

Solso, R. I. (1979). Cognitive psychology. New York, NY: Harcourt Brace Jovanovich, Inc.

Stedman, R. C. (1996). Sense of place through hunting: A constructivist approach to landscape identity. In the Sixth International Symposium on Society and Resource Management: Social Behavior, Natural Resources, and the Environment (p. 193). University Park, PA: The Pennsylvania State University.

Stokols, D., \& Shumaker, S. A. (1981). People in places: A transactional view of settings. In J. Harvey (Ed.). Cognition, social behavior, and the environment (pp. 441488). Hillsdale, NJ: Erlbaum.

Tilden, F. (1977). Interpreting our heritage. (3rd ed.). Chapel Hill, NC: University of North Carolina Press.

Trotter, R. T. Jr. (1992). Monster time and other ethnographic insights at Wupatki National Monument. In G. E. Machlis \& D. R. Field (Eds.), On interpretation: Sociology for interpreters of natural and cultural history (Rev. ed., pp. 129-149). Corvallis, OR: Oregon State University Press.

Tuan, Y. F. (1974). Topophilia: A study of environmental perception, attitudes, and values. Englewood Cliffs, NJ: Prentice-Hall.

Tuan, Y. F. (1976). Geopity: A theme in man's attachment to nature and place. In D. Lowenthal \& M. Bowden (Eds.). Geographies of the mind: Essays in historical geosophy in honor of John Kirtland Wright. Oxford, England: Oxford University Press.

Tuan, Y. F. (1977). Space and place: The perspective pf experience. Minneapolis, MN: University of Minnesota Press.

Tuan, Y. F. (1980). Rootedness versus sense of place. Landscape, 24, 3-8.

Wagar, J. A. (1975). Effectiveness in interpretation. The Interpreter, 7(3), 6-11.

Wagar, J. A. (1978). Why interpretation?: Meeting the challenge. Journal of Interpretation, (3) 1, 6-10.

Wallace, V. K., \& Witter, D. J. (1991). Urban nature centers: What do our consistence want and how can we give it to them? Legacy, 2(2), 20-23.

Wang, T. L. (1998). Interpretation initiative in the National Park Service: Testing theory, improving practice, and monitoring visitor outcomes. Unpublished manuscript, West Virginia University. 
Wasserman, J. R. (1998). To trace the shifting sands: Community, ritual, and the memorial landscape. Landscape Journal, 7(1), 42-61.

Weber, R. P. (1990). Basic content analysis. (2nd ed.). Newbury Park, CA: Sage Publications.

Wiersma, W. (1995). Research methods in education: An introduction. Needham Heights, MA: Allyn and Bacon.

Williams, D. R., Patterson, M. E., Roggenbuck, J. W., \& Watson, A. E. (1992). Beyond the commodity metaphor: Examining Emotional and symbolic attachment to place. Leisure Sciences, 14, 29-46.

Williams, D. R., \& Roggenbuck, J. W. (1989, October). Measuring place attachment: Some preliminary results. Paper presented at the NRPA Symposium on Leisure Research, San Antonio, TX.

Williams, D. R., \& Stewart, S. I. (1998). Sense of place: An elusive concept that is finding a home in ecosystem management. Journal of Forestry, 96(5) 18-23.

Zinsser, W. K. (1992). American places: A writers' pilgrimage to 15 of this country's most visited and cherished sites. NY: Harpers Collins. 


\section{Appendix A: \\ NCP_Central Visitor Focus Group Interviews Quotes-War}




\section{War Quotes}

- This setting is being used for this one concept-freedom. Which is-Martin Luther King said in his great speech, "Let freedom ring." And there's a lot of people in the country who say are we free or aren't we free? But freedom comes at a great cost with the lives that were lost in the wars. (Man, Pre 1, p. 7)

- I think a lot of people don't realize how the laws and everything that went on in those periods as affected our life today. I mean, remnants of every war is still a part of what we do in our everyday life. And technology - technology from wars is with us every single day now. You can get on your computer and you can get on your telephone or get in an airplane. It's pretty amazing. And all these people came together and worked and put that together. We have the benefits of that. (Woman, Pre 1, p. 5)

- MD: What does the sites teach us?

Man 1: They teach us war is horrible. (Pre 2, p. 3)

Man 2: [The sites represent] national will or lack of national will. Because, I mean, Vietnam was a very perfect example of the lack of national will on our part to carry through. That was more of a government mandated war you know, so to speak. It all depends on how you look back on history. But you know there are a lot of other side issues that went into that as opposed to the broad-bases support of say something like World War I or World War II. We didn't quite have that with these final two wars. It's kind of a crossroads in our own history. (Pre 2, p. 4)

- [The Vietnam War Veterans Memorial] represents Sacrifice, honor, valor, I mean, a lot of people they didn't really know what they were doing. It is like WWII, everybody went, no questions asked. This war kind of represents the war where all the questions got asked. And a lot of them through participants. (Man, Pre 3, p. 4)

- But what these three monuments here mean is [inaudible]. What I mean by that is that the spirit that pervades these grounds, is the spirit of sacrifice and humility, but 
at the same time greatness. Because the people who died here, left their mark here, and left their mark on this whole country. The dream is not quite finished, but it is still in the process of becoming a flower which will...[inaudible]. All these three sites come together and they bring that [message] — without pain there is no gain. I do believe that places like this are the cathedral of the soul. They bring out the depth of all human beings and you begin to see what a nation is supposed to do to make all living things free. (Man, Pre 4, p. 4)

- MD: What does the site teach us?

Man1: (Responded immediately): War sucks.

Woman: In no uncertain terms. (Laughing). (Pre 5, p. 6)

- He was in Korea. (Another participant in the focus group) He went to Korea. But we have friends who served in Vietnam. We know people who served there. It was a terrible terrible war! My friend Neil from Florida - that is where they live now. They are taking us on a tour at Washington. Neil told me that when Vietnam started he was much younger. He was a Hawk. And I almost asked him in disbelief, why were you a Hawk? Well, and he explained it to me. And then he quickly changed and became a Dove. And I will let Neil tell you. (Man, Pre 5, p. 2)

- It was coming from one conflict to another, you wanted to see a decision of some sort. You want to win a war; lose a war; or you shouldn't be there. When it started, I was very much, you know, let's get this over and get this done. Then I came to the realization (speaker chokes back some sobs), they didn't want to win. They were just there to...to have their body counts and... (Man, Pre 5, p. 2)

- Man 1: The Korean War, the Vietnam War, were not an "American" War. Woman 1: Well, they were not American wars but the soldiers fought for whatever they believed in at that time.

M1: That part is fine.

W1: So therefore, they are still fighting it. 
M1: But they didn't protect our rights. They went and fought in a strange country... W1: Well, America-so they helped other people. (Pre 5, p. 9)

- Nobody really wants to go and die for their country. But sometimes, it's something that has to happen. I don't know that necessarily the Civil War had to happen...but somebody had to fight, somebody called them out to fight. And they fought; they served their country. It's ended, obviously, most of these had ended... there is closure, obviously for something like the Vietnam Memorial, for some folks there will never be closure. (Woman, Pre 11, p. 7)

- I am a teacher in Wyoming, I grew up at Pennsylvania. People in the West don't travel here, so they don't understand what our country is about. The pain of the wars, people just don't understand that now. So I think it's good to understand the struggles that we've had to have what we have today. No other country has anything like what we do. (Woman, Post 1, p. 3)

- You know, listening to this whole conversation, what's interesting to hear and what you're saying, maybe our approach to teaching history needs to be examined in that we look at the big picture, because those are the type of questions you are asking. The big picture questions... what is coming out of these wars that's affecting us as a people, as a nation. And maybe the focus of how we teach it to the kids might be, you know, what have all these conflicts and wars given us, or not given us, or [how have they] made us what we are today? [We could] look at it as a big picture instead of individual actions... (Woman, Post 3, p. 10)

- Man 1: But another important point is that Lincoln believed deeply that the Civil War was about penance. We as Americans, both North and South, had committed a crime by buying into slavery. And we do not know when the war would end-there was the sentence there-maybe it will not end until every drop of blood is paid for with a drop of blood. That is very important. Americans tend not to want to think about the dark side. And what we have done is wrong. And that is something we 
can have with a historical perspective, [we can have] a new attitude. Lincoln is very contrasting, and maybe Americans can share that feeling, the sense that this is our penance, and this war is going to go on until God has decided that we paid for it. W: Maybe we have not paid for it yet.

M1: Exactly.

$\mathrm{W}$ : So there should be a connection with now and the past. What he saying is what we really accomplished, perhaps we didn't. (Post 4, pp. 10-11)

- I think the importance of, the reason why we have memorials is that they are like cemeteries or tombstones that you can go to and if you were involved or your family, you can go and feel the passion. But also for those who have never been to the war, for them to realize that people actually die. Sometimes we glorify war, people see marching bands and that kind of stuff. The veterans are hidden away. The importance is to realize how lucky we are, especially when we think about all the other countries. We do have politicians to what the goals are. We can sit down and negotiate at the table, [we can consider] all the possibilities. Some wars are avoidable. (Woman, Post 5, pp. 2-3)

- War is something that governments have-government policy, not people. People want peace. People want quiet. Now they built all the monuments for the peace, and for the people who fought for that. (Israeli woman, Post 6, p. 3)

- They teach us about the frailty of men and their ideas. All these wars could have been avoided. I mean, the Vietnam War, I grew up during it. We weren't really fighting for our country. It was a divided war. And it even divides the internal country here today. The Civil War divided the country—so two out of three of these...The Korean War was a little before my time, I don't know the exact history, but I guess we were fighting Communism. The ideologies men had. The Bible does say there will be wars and rumors of wars... (Man, Post 8, p. 3) 
- I think it's a reminder of what war does. It kills people. I mean, how many names are on that wall there?...Lincoln's second inaugural speech kind of brings war out. But that isn't what I was thinking about when I went up there. (Man, Post 9, p. 8) 
Appendix B:

NCP-Central Visitor Focus Group Interviews Quotes-Lincoln 


\section{Lincoln Quotes}

- The statue of Abraham Lincoln. I always wanted my picture to be, to have a picture close with the great man who had made the important, I will say, history of making this country. I think he was one of the first and the most important ones. (Man, Post 1, p. 2)

- Something that strikes me is not just Abraham Lincoln. I have a second cousin whose name we go see on the Vietnam Wall. Our country stands for not just heroes like Lincoln but all people. That is what I think of all those monuments. It is really wonderful to be in a country that lifts up Lincoln and lifts up my cousin. (Woman, Post 1, p. 4)

- Woman 1: We had some great men in this country, to be sure.

Woman 2: But in order for Lincoln to be great, he had to have the ordinary guys or persons to do the job. Because without that...

Woman 1: I think what it really says to me is the willingness of the American public to participate in any conflict that will make sure that we have freedom. (Post 3, p. 4)

- The United States is for that regretfulness for things that we have done in the past for the world. But there are things in the "dark side" that United States is also about. And Lincoln reminded us that we are showing the country and the world that we still have wars between religions, and wars between the governments of Communism or Socialism against democracy. (Man, Post 4, p. 4)

- This is an opportunity for us to show the rest of the world that our ideals are supposed to be, and when we do something stupid, and when we show the wrong side of ourselves, maybe people coming here will say, "Somebody made a mistake, but this is what America really means. This is not about this gentleman sitting on the chair, it is about what these things tell us. (Woman, Post 4, p. 5) 
- I think there is a lot to show the young people. To see that there are a lot of heroes and these people are probably just regular people. But when the situation fell upon them, they became heroes, because they did what they had to do and did it right. That would be anybody. So the children of today are going to be our presidents and heroes tomorrow. (Man, Post 4, p. 7)

- Man 1: But another important point is that Lincoln believed deeply that the Civil War was about penance. We as Americans, both North and South, had committed a crime by buying into slavery. And we do not know when the war would end-there was the sentence there-maybe it will not end until every drop of blood is paid for with a drop of blood. That is very important. Americans tend not to want to think about the dark side. And what we have done is wrong. And that is something we can have with a historical perspective, [we can have] a new attitude. Lincoln is very contrasting, and maybe Americans can share that feeling, the sense that this is our penance, and this war is going to go on until God has decided that we paid for it. Woman: Maybe we have not paid for it yet.

\section{Man 1: Exactly.}

Woman 1: So there should be a connection with now and the past. What he saying is what we really accomplished, perhaps we didn't. (Post 4, pp. 10-11)

- I remember being a little girl with my parents. And every time I read anything about him or learned anything about him, I pictured, the memorial, the statue. I then I brought my children back and I felt a little more in charge. Because I am this tall, much taller. And now I feel more in charge. And for myself I have more understanding of it. It is good to get that feeling. You are supposed to be inspired by something powerful and by the ideals. (Woman, Post 4, p. 12)

- Abraham Lincoln is my favorite president. He is very inspirational, clearly a man who had a heart. (Woman, Post 6, p. 2) 
- I cannot picture the Lincoln Memorial in any other way than now. But that reflected everything of that particular time for all the states, the union. It is very much like a temple for Lincoln. It is more than what he was, that he served at such an important time in our history defines who are today. I think it gives a rebirth to freedom so to speak in such a grand monument. The whole era we cannot even imagine what that was like. (Man, Post 7, p. 3)

- Man 1: "Perseverance is the word for Lincoln for sure. He failed so many times at elected office before he was elected as President. Before he was elected to Congress, he failed many, many times."

Man 2: "He should be on more than the penny." (Post 8, p. 3)

- Woman: Lincoln had such a hard life. He failed in business three or four times. He had a nervous breakdown. He lost children. He lost his first love-she was not his wife. Yet he persevered. [He is] considered to be a great man now, and he was. Man: He never quit. (Post 8, p. )

- One of the things I think of, especially as I was reading the Second Inaugural [Address] and the Gettysburg [Address], I just wish we had statesmen like he was today - and in the future. It just seems like times have changed, but he was a rare man. And I just wish we had more people like him. (Man, Post 8, p. 4)

- I think people go up there and [see him] as a father figure. (Man, Post 9, p. 4)

- Woman 1: "I really think the Lincoln Memorial reminds us....the whole thing, the Jefferson, Washington, the whole memorial park here, just reminds me of our heritage. We were just walking down the Mall here by the reflecting pool telling [my daughter] that the ground that we walk on belongs-a little bit of it belongs to everyone one of us in the country." 
- MD: What kind of word would you wrap around it if you were trying to verbalize what it stands for?

Woman: Oh boy. Independence, honor, pride. (Pre 1, p. 5)

- The power and the significance a really strong and charismatic leader can have on a nation. He kept the nation together. The importance of the leader at that time. Lincoln couldn't have done what Washington did. Washington couldn't have done what Lincoln did. They both together maybe couldn't have done what Jefferson did. Each one is unique for what they did for the country. There is a stark contrast between all of them. They all had a key role to play... (Man, Pre 3, p. 5)

- I think the Lincoln Memorial reminds me how important it is that we stay united as a nation. And how important it is that everyone is equal in our nation. I really admire Abraham Lincoln — his integrity and what he stood for, that he stood by what he believed in no matter what happened. I really admire him for that. That means a lot to me. (Woman, Pre 4, p. 2)

- I do not know. When I look at Lincoln, I just feel inside warmth or something...It is very difficult to explain. It is something that makes your body, kind of shake and say "I am proud to be part of this country." (Woman, Pre 5, p. 1)

- Man: "In another words, it's public land." Woman: Yeah, and when I walked down these paths I think of all the great rallies that have taken place here. Even up to last year, the Promise Keepers' Rally with millions of men praying for our country. It is just amazing. And Martin Luther King's rally here...All the great things that have happened on this ground. It is really neat." (Pre 4, p. 6)

- I don't care if I see anything else except the Lincoln Memorial. I've always had a special place in my heart for the struggle of the Civil War and what it all meant. It is very special to me. (Woman, Pre 11, p. 2) 
- I think it is all overwhelming. It is hard to take it all in at one time. So, I'll have to come back, multiple times. I don't think you can really get a true feeling for what it is [in] one time or two times. (Man, Pre 11, p. 5) 


\section{Appendix C: \\ NCP_Central Visitor Focus Group Interviews Quotes-Democracy}




\section{Democracy Quotes}

- Even just walking up here, I mean, I was recalling that Dr. King had spoken here and other events had taken place here. And to just associate that as a big, you know, like meeting ground for different causes and protesting of the war in Vietnam. It's just a symbol. (Man, Pre 2, p. 5)

- Woman 1: We had some great men in this country, to be sure.

Woman 2: But in order for Lincoln to be great, he had to have the ordinary guys or persons to do the job. Because without that...

Woman 1: I think what it really says to me is the willingness of the American public to participate in any conflict that will make sure that we have freedom. (Post 3, p. 4)

- Woman 1: All these sayings are tremendous because we have forgotten them. That was a long time ago. He had tremendous [influence] and he lived by what he said. Woman 2: I always want to say, "How are we doing today?" (Post 3, p. 9)

- But see, we were different then. And we have a higher responsibility than other nations because we are the ones who said that "All men are created equal." And we are the one who set ourselves up as the supporters of that ideal. Other countries did not do it. Nobody else ever made that promise or claim. And if we are going to make it and we've made it for two hundred and twenty years now, if we are going to make that claim, then we have the responsibility to at least attempt it We are all human and no one is going to achieve that. We have a high responsibility to attempt it. (Man, Post 4, p. 6)

- The other problem is that we used to open our arms to people from all other countries, and now we don't. (Man, Post 4, p. 6) 
- Woman (asking her granddaughter): What are you going to do when you grow up now?"

Child: "I am going to be a president."

Man (the grandfather): "What can a president do?"

Child: "A lot of things."

Man: "But you could not be a president because why?"

Child: "Because I am a girl."

Woman (the grandmother): "So you beat them up, didn't you?"

Child: "Yeah!"

W (the grandmother): "Good."

M (the grandfather): "So you are going to be the first woman president."

W (the grandmother): "Yeah, after we beat them up!"

(All participants were laughing!)

W (the grandmother): "No, there is going to be someone." (Post 4, pp.7-8)

- I think the most important thing is that these are memorials to the people that died to keep our country free, and safe for democracy. And more than anything else, that's what it's about. The people that paid with their lives for freedom, for democracy. (Man, Post 8, p. 7) 


\section{Appendix D: \\ NCP-Central Visitor Focus Group Interviews Quotes-Patriotism}




\section{Patriotism Quotes}

- They bring the emotion to it, the humanity to a building or an area. And let's not forget these are buildings, but they generate a feeling of emotion that's been--human rights or the anti-war demonstrations or whatever, but it brings people together, as such. I mean, let's not forget they're a glorification as well. It's like, hey, look at us. We're the best, which I find very American. But you've got to take it with a sense of levity and not take it too seriously, you know. It's Americanism. It's what, like you say, it's what means a lot of things to Americans and people from around the world. Through movies and, you know, I recognize these buildings without ever being here. (Woman, Pre 2, p. 5)

- I was dreaming to death to go to Washington, DC I gave never been and I think people from other countries, the first thing they want to see is here the Capitol. (Woman, Pre 7, p. 2)

- The statue of Abraham Lincoln-I always wanted my picture to be, to have a picture close with the great man who had made the important, I will say, history of making this country. I think he was one of the first and the most important ones. (Man, Post 1, p. 2) 


\section{Appendix E: \\ NCP_Central Visitor Focus Group Interviews Quotes-Freedom}




\section{Freedom Quotes}

- This is the birth place of liberty and freedom and I don't really know your American history very well. But I do know like Lincoln. He was sort of talking about the Civil War wasn't about liberty. It was secession of the Southern States and he wanted to prevent that and preserve the United States so it'd be really cool seeing it (Woman, Pre 2, pp. 2-3).

- MD: So for the war memorials, they commemorate people. And do they teach us something about—do they teach us anything?

Man: They teach us war is horrible.

Woman: The price paid for liberty. There you go. I mean, we are walking around, but these actual people gave up their lives for us, you know. I mean that's a very general statement but it's true. They fought. Some of them didn't want to. Some of them were drafted. They died there. And it's like they died so we could be free (Pre 2, p. 3).

- I think we're even farther. I mean that's the price of freedom, actually. I think it is we have the freedom to choose and be able to question why it is that we' re doing things. Being in the military, I mean, obviously we don't really get a choice of what we want to do or what we don't want to do but as a civilian you very much have a right to call up your congressman or anyone so you can know why. That's why Desert Storm was such a big deal. We only gave broad-based support when we started winning. But for those first six months prior to that, you know, there were a lot of demonstrations right here. You know, why are we even in there? "Blood for oil" I remember was the big slogan while I was waiting to be sent out myself (Man, Pre 2, p. 4).

- Even just walking up here, I mean-I was recalling that Dr. King had spoken here and other events had taken place here. And to just associate that as a big, you know, 
like meeting ground for different causes and protesting of the war in Vietnam. It's just a symbol (Man, Pre 2, p. 5).

- MD: What do these sites teach us?

Woman 1: All of them have to do with freedom. Starting with Lincoln, the Vietnam one is so touching, too. But I had relatives who fought in the Korean one. They all have to do with freedom. Like the words said, "Freedom is not free." When you go to the Vietnam one, it is just overwhelming. At this one [Korean], you can see the pictures of those who fought."

Woman 2: The loss of lives for the price of freedom was so much more costly. It seems like the Vietnam has so much of a negative emphasis. As an older person, it bothers me. Because a lot of people paid a very high price for the freedom-I wonder if they appreciate it (Post 5, p. 2).

- Man: That was great. Because he is a gentleman who had been there. He has the passion of the events, what occurred...

Woman: Particularly when he mentioned the flag. Whenever you see one of those, you know, that is the one. It is for freedom. I thought that was real personal (Post 5, p. 4).

- "Freedom is not free" is a very powerful emphasis, just like democracy. For those people who miss the corner (where the message is etched) will miss the message I think there should be a sign right there saying "Freedom is not free," right at the central point (Man, Post 5, p. 4).

- MD: Do you think there are aspects of the memorial that help us, or teach us about people and issues that relate today...

Woman: Kind of. Seeing that he freed the slaves. You can see "freedom." Man: I think that, like you said, it's an ideal. I don't know that it was his ideal that all people would be equal, not necessarily that it's true yet. But it's an ideal to strive for I guess. I don't think that it's true that people are equal, but it was an ideal that 
was ahead of its time. That's why he was unpopular. And it has to do with the economy too (Post 9, p. 5).

- Man: This setting is being used for this one concept — freedom. Which is-Martin Luther King said in his great speech "Let freedom ring." And there's a lot of people in the country who say are we free or aren't we free? But freedom comes at a great cost with the lives that were lost in the wars.

Woman: And there's different levels of freedom. And that's when you have to be reminded too (Pre 1, p. 7).

- Woman: What does it mean to you?

Man: Me? Again, freedom and someone who stood up for what he believed and went against a lot of opposition just to go with what he thought (Pre 1, p. 9).

- Man: However big the problem, and however diverse the people involved, if you all have a common goal you can get together and do it. All races, all religions, they experience what's gone on that these [sites] memorialize. And we've all put it together in the U.S. together.

Woman: Freedom, patriotism, how everybody makes a difference, and how personally it touches so many people who walk by the memorial, the Vietnam War Memorial. We see so many photos or letters...(Post 1, pp. 4-5).

- Man: But see, we were different then. And we have a higher responsibility than other nations because we are the ones who said that "All men are created equal." And we are the ones who set ourselves up as the supporters of that ideal. Other countries did not do it. Nobody else ever made that promise or claim. And if we are going to make it and we've made it for two hundred and twenty years now, if we are going to make that claim, then we have the responsibility to at least attempt it. We are all human and no one is going to achieve that. We have a high responsibility to attempt it.

W: I think the memorials show us that (Post 4, p. 6). 
- I think today's children do not have enough freedom language of what people had gone through, so that they can have freedom they have now I do not know. I am not even sure my children will know. I think a lot of kids do not know what their aunts, their uncles, even their grandparents went through to make sure they are still here enjoying the freedom. I do not think that is taught enough (Woman, Post 3, p. 4).

- Woman 1: I think the saying at the Korean Memorial, "Freedom is not free," I think that is [something] that people should sit and think about for a while. And that is in any generation. This freedom that we enjoy today is not free. And this is what I thought about. And that would apply to any of the wars.

Woman 2: Or not even wars, just history in general (Post 3, p. 8)

- I think it is not easy to maintain your independence and your freedom. All [the memorials] reflect a lot of suffering and dying, and Lincoln. So when you come here, it is special to see what these folks have done so that we can walk around and do what we want to do (Man, Post 7, p. 2).

- I cannot picture the Lincoln Memorial in another way than now. But that reflects everything of that particular time for all the states, the union. It is very much like a temple of Lincoln. That is more than what he was, what he [did] at such an important time in our history defines who we are today. I think it [gives] rebirth to freedom so to speak in such a grand monument. The whole era we cannot even imagine what that was like (Man, Post 7, p. 3).

- I see these sites as having an overpowering message of freedom (Man, Post 8, p. 3). 


\section{Appendix F: \\ NCP-Central Visitor Focus Group Interviews Quotes- \\ Intergenerational Experience}




\section{International Experiences Quotes}

- I think it's a great tradition that Native Americans have taught their culture passed down in an oral history and that, I believe, is primarily what people ought to do when you bring them here. Passing on you experiences and the experiences of your forefathers and whatever else brought you here the first time or whatever else you might have learned. Because there are insights into history that you just can't get from books. (Man, Pre 2, p. 6)

- I was explaining to my aunt that was important that we bring some of our younger relative or kids down to get a feel and a sense of what the country is about, which is sort of embodied here in the memorials, in the monuments, and in the government buildings. I think in that way it kind of gives them a better sense of what our country is about. And they can obviously as they grow and develop they can have a sense... (Woman, reserved army officer, Pre 11, pp. 2-3).

- Woman 1: I came here because when I was my son's age, I remembered my parents bringing me here, and it being an especially wonderful place to have history come alive. I am hoping that they're enjoying it.

Child1: Sure.

Woman 2: I always wanted to come here when I was her age and never had the opportunity. And so I made sure that my daughter would have the chance to come and see. It has just been overwhelming. (Post 1, p. 1)

- That is something that is multigenerational. Because I came the first time with my parents, and I came the second time with my children. And I came the third time with my grandchildren. (Woman, Post 4, p. 7)

- Not only should it be inter-generational, but I also think you have to come different times in your own life. For one thing, you have different perceptions and different 
experiences at different points. We relate this way when you are 20, and I imagine when you are 50, you will relate on another level as well. (Man, Post 4, p. 12)

- I remember being a little girl with my parents. And every time I read anything about him or learned anything about him, I pictured, the memorial, the statue. I then I brought my children back and I felt a little more in charge. Because I am this tall, much taller. And now I feel more in charge. And for myself I have more understanding of it. It is good to get that feeling. You are supposed to be inspired by something powerful and by the ideals. (Woman, Post 4, p. 12) 
Appendix G:

NCP_Central Visitor Focus Group Interviews Quotes-Interpretation 


\section{Interpretation Quotes}

- I just thought that [ranger program] was an incredible presentation, probably one of the best I've ever heard. I really appreciate the way the ranger made the whole thing come alive. And I thought about it in terms of how unpopular Lincoln was in his day and yet he persevered and stuck with his ideas. The ranger talked about Lincoln's press and how he was maligned in the press on a daily basis, and yet he stuck with his ideals. I like that the ranger shared that with people - the struggle that Lincoln went through (Man, Post 1, p. 6).

- The interesting is that Lincoln is a symbol of this country. But when the ranger went and asked everybody, there were very few people from the same state-Alaska, foreign countries_-very few people were actually from one state. It is multi-cultural, with different attitudes, different expressions. That is what this country all about (Man, Post 1, p. 6).

- Woman 1: "One thing that I thought was interesting [was] when I first got over there, there's so many things that we go to where there's like a plaque or something giving an overall view of what's there. And the way we went in, I saw nothing. I like to process information and [not fulfilling] that bothers me. There wasn't anything there. And had I not been lucky enough to be there [to hear the ranger program] I probably would've walked away with a lot of questions in my mind."

Woman 2: "I felt like I was in limbo.” (Post 3, p. 8)

- The program was great. Because the ranger is a gentleman who had been there [the battlefield]. The ranger has the passion of the events, and of what occurred. It was still very close to the ranger. At our age, we have just heard about it, but we don't 
have an understanding about the topic and what just happened there. It was not just like other tour guides. This is a man with a passion. Because he can speak of ityou knew it was from the ranger's heart. It is good to listen to the ranger's talk (Man, Post 5, p. 3-4).

- Because that [Freedom is not free] is the high tide of the memorial. That ties into the Lincoln Memorial and the Vietnam Memorial. Something to give you some understanding of what the memorial demonstrates also. Because we walked through and we didn't understand what we were seeing. What the ranger described about changed the whole picture for us. We were not educated too much at the Korean War. We saw that and I said, 'Yeah, I recognized it for what it is.' But I don't know what it means (Man, Post 5, p. 4).

- The Lincoln Memorial, he is obviously was a very dynamic person. He went through very tough times in the nation's history. I just wanted to be there and read the Gettysburg Address and the Second Inaugural Address. You do get a special feeling, especially listening to the ranger's talk. He is very good, very passionate. (Man, Post 8, p. 2)

- I think the ranger touched on that a little bit when he said that he saw that there were parents here with children and [asked] "How would you feel if you lost a child?" The ranger was pointing out that Lincoln lost more than one child. It is true of all these memorials. Like the ranger said, “That's somebody's brother, somebody's son, and somebody's father" (Woman, Post 8, p. 7).

- Man 1: "The ranger's enthusiasm, that grabbed me. I heard the ranger talking and I turned around. Then I got closer and I got closer and I got closer. The ranger was so enthusiastic that $I$ got excited."

Man 2: "We were there from the very beginning. And there was just a very small group there. But the more the ranger talked, and the ranger got louder as the ranger 
went—louder and louder and more passionate...and more people came flocking in" (Post 8, p. 7).

- You really can get a feeling of it. Like the ranger said, we wonder what would Lincoln think if he walks up to the memorial, because he was not a popular president. A man of his time, he would not expect it. I thought the ranger did a good job to bring all the perspectives of the Vietnam War. The ranger didn't go to the Korean and the Vietnam War, but you can get a sense of them. The grand idealrighteousness and what war was all about (Post 9, p. 4). 


\title{
VITA
}

\section{NAME \& ADDRESSES}

Wei-Li Jasmine Chen

Division of Forestry,

P.O. Box 6125

Morgantown, WV 26506-6125

Ph. (304) 293-2941, ext. 2304

E-mail:wchen3@wvu.edu

\section{FORMAL EDUCATION}

\author{
a. Undergraduate \\ Degree: B.A. \\ Year: 1995 \\ Institution: Providence University, Tai-Chung, Taiwan \\ Major: English Language \& Literature \\ b. Master's degree \\ Degree: M.S. \\ Year: 2000 \\ Institution: West Virginia University \\ Major: Recreation, Parks, and Tourism Resources \\ Thesis Title: Exploring Visitor Meanings of Place in the National Capital Parks-Central \\ (Advisor: Theresa L. Wang) \\ c. Doctoral Education \\ Degree: Expecting Ph.D. \\ Year: 2002 \\ Institution: West Virginia University \\ Major: Forest Resource Science
}

\section{PROFESSIONAL EXPERIENCE}

Research Assistant, May 1998 - present: West Virginia University, Division of Forestry; Worked on a collaborative project with the Mather Training Center, National Park Service, related to interpretative theory, professional development and training, and assisted with focus group interviews on a visitor meanings of place study.

Teaching Assistant, September - December 2000: Department of Recreation, Parks, and Tourism Resources and Landscape Architecture, West Virginia University; Assisted in "Meanings of Place" course, assisted on the development and management of the course website, conducted computer skill workshops, led class discussion, and participated in two of the Community Design Team visits: Grantsville and Madison, West Virginia University 
Seasonal Natural \& Heritage Resources Interpreter, July 1993 - December, 1996: Kenting National Park, Taiwan; Responsible for interpreting the flora, fauna, geography, anthropology, and ecosystem of the park resources to general visitors. Also conducted environmental education programs for all ages, from elementary school to college

Liaison \& Communication Administration Staff, December 1995 - April 1998: Green Party Taiwan, Taipei, Taiwan; In charge of all aspects of legislative planning and lobbying, from communicating with external organizations regarding legislation, to coordinating discussion, and formally preparing the official stand of Green Party Taiwan.

Field Investigator, August 1994 - March 1995: Wild Bird Association of Taiwan, TaiChung, Taiwan; Assisted in the bird population investigation in the elevated forest around the source of the Da-Jar River.

Volunteered Exhibit Interpreter, June 1994 - Janurary 1995: National Natural Science Museum, Tai-Chung, Taiwan; Led interpretative hand-on programs of the Methods of Ceramic Art in Ancient China Exhibit.

Summer Youth Camp Leader, May 1992 - August 1992: YMCA, Tai-Chung Branch in Taiwan; Assisted in the Nature Discovery Program and hands-on observation.

\section{PROFESSIONAL SERVICE AND INVOLVEMENT}

a. Organization memberships

National Association of Interpreters

National Recreation and Park Association

Xi Sigma Pi - National Forestry Honors Society

Association of Kenting National Park Interpreters

b. Major speaking engagements and presentations

National

Chen, W.L., Wang, T. L. and D. L. Larsen (1999, April). Exploring Visitor Meanings of Place and Enriching Interpreter Knowledge of the Audience in the National Capitol Parks. Paper presentation at the 1999 Northeastern Recreation Research Symposium. Bolton Landing, New York.

Wang, T.L., Chen, W.L., and D.L. Larsen. (1999, March). Connecting Visitor Meanings of Place to Resource Stewardship. Paper presentation at the 10th Conference on Research and 
Resource Management in Parks and on Public Lands, The George Wright Society Biennial Conference, March 21-26, 1999, Asheville, North Carolina.

Wang, T.L., Chen, W.L., and D.L. Larsen. (1998, October). Interpretation Initiatives in the National Park Service: Understanding Visitor Meanings. Paper Presentation at the National Association for Interpretation's National Interpreters Workshop, October 20-24, 1998, Anchorage, Alaska.

c. Honors and awards

Outstanding Lecturer in Summer Natural Resources Research Camp, The Ministry of Finance, Taiwan. (1993, August).

Model of Student Award: for outstanding academic and extracurricular performance , Providence University, Taiwan. (1992, May).

\section{$\underline{\underline{P U B L I C A T I O N}}$}

Wang, T.L., Chen, W. L. and Larsen, D. L. 2001. (Accepted in October, 2000). Clicking the Icon: Exploring the Meanings Visitors Attach to Three National Capitol Park Memorials. The Journal of Interpretation Research. 